\title{
A comparative analysis of anti-trafficking intervention approaches in Nepal
}

Catrin Evans

Pankaja Bhattarai

Celine Daly

Population Council

Vaishali Sharma Mahendra

Population Council

Nick Langton

Follow this and additional works at: https://knowledgecommons.popcouncil.org/departments_sbsr-pgy

Part of the Human Rights Law Commons, and the International Public Health Commons How does access to this work benefit you? Let us know!

\section{Recommended Citation}

Evans, Catrin, Pankaja Bhattarai, Celine Daly, Vaishali Sharma Mahendra, and Nick Langton. 2000. "A comparative analysis of anti-trafficking intervention approaches in Nepal." New Delhi: Population Council. 


\title{
TRAFFICKING IN NEPAL: INTERVENTION MODELS
}

\author{
A Comparative Analysis of \\ Anti-Trafficking Intervention \\ Approaches in Nepal
}

Prepared by:

Dr. Catrin Evans

Ms. Pankaja Bhattarai

December 2000

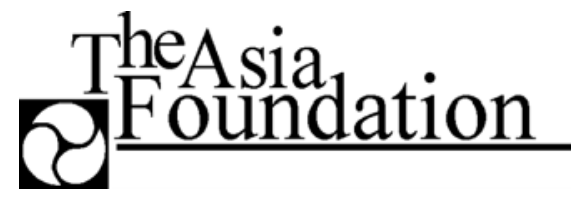

Kathmandu, Nepal

Nick Langton, Representative

Pankaja Bhattarai, Program Officer

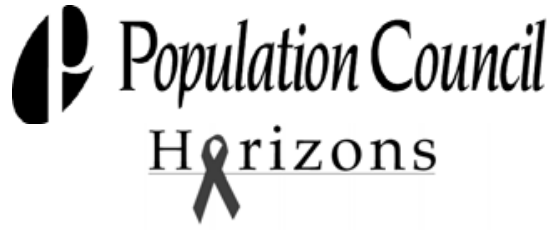

New Delhi, India

Dr. Celine Costello Daly, Program Associate Vaishali Sharma Mahendra, Program Officer 


\section{Acknowledgments}

We gratefully acknowledge all those who were interviewed for this report in Kathmandu.

In addition, the following persons contributed to this report: Mr. Chris Parker, consultant editor, Population Council, New Delhi, and Ms. Patricia Roberts, editor, The Asia Foundation, Kathmandu.

\section{For more information:}

The Asia Foundation

P.O. Box 935, Baluwatar

Kathmandu, Nepal

Tel: $977-1-418345,411458$

Fax: 977-1-415881

Email: nick@taf.org.np
Horizons Project

Population Council

53 Lodi Estate

New Delhi 110003

India

Tel: 91-11-461-0913

Fax: 91-11-461-0912

Email: horizons@pcdc.org

www.popcouncil.org

This publication was made possible through support from the Office of Health, Nutrition and Population, Global Bureau, U.S. Agency for International Development, under the terms of HRN-A-00-97-00012-00. The opinions expressed herein are those of the authors and do not necessarily reflect the views of the U.S. Agency for International Development. 


\section{Executive Summary}

\section{Background}

This report on current intervention models is part of a larger research study entitled "Intervention Needs for the Prevention of Trafficking and the Care and Support of Trafficked Persons in the Context of an Emerging HIV/AIDS Epidemic in Nepal." The United States Agency for International Development (USAID) supported this comprehensive study under the Population Council's Horizons Program. The Population Council in turn subcontracted The Asia Foundation in Kathmandu to conduct the research.

The objective of this report is to "document and analyze current intervention models for the prevention of trafficking and the care and support of trafficked persons in Nepal." Between August and September 2000, two researchers interviewed four key informants, one donor agency, two international and eight local NGOs based in Kathmandu. All of these individuals and organizations support or implement antitrafficking programs, or have extensive knowledge of trafficking-related issues in Nepal.

This research aims to understand current perceptions of trafficking and identify the assumptions that explicitly or implicitly inform intervention approaches. A comparative analysis of different intervention approaches (including their content and process) was made using a human rights framework. Issues of feasibility, coverage, effectiveness and sustainability were considered. Finally, lessons learned are highlighted. The research analyzed different intervention approaches as follows:

\begin{tabular}{|c|c|}
\hline 1. Trafficking Prevention & $\begin{array}{l}\text { - } \text { Rural-based interventions } \\
\text { - } \quad \text { Urban-based interventions } \\
\text { - } \quad \text { Border-based interventions }\end{array}$ \\
\hline $\begin{array}{l}\text { 2. Care and Support of } \\
\text { Trafficked Women and Girls }\end{array}$ & $\begin{array}{ll}\text { - } & \text { Girls who return home } \\
\text { - } & \text { Girls who do not/cannot return } \\
& \text { home } \\
\text { - } & \text { Girls who are HIV positive } \\
\text { - } & \text { Rescue and interception } \\
\text { - } & \text { Legal assistance } \\
\end{array}$ \\
\hline 3. Networking and Advocacy & - General comments and analysis \\
\hline
\end{tabular}

Issues pertaining to monitoring and evaluation, as well as specific recommendations are found at the end of the relevant three sections. 


\section{Conceptual Clarity}

Overall, the study found that there is a lack of reliable research to make informed interventions in Nepal. Current interventions are based on anecdotal evidence about the magnitude and process of trafficking. This lack of information has contributed to a lack of conceptual clarity among some organizations that have confused trafficking with issues such as legal/illegal migration and sex work. Some organizations appear to focus their anti-trafficking programs on "protecting" women by preventing their movement within or outside the country. Consequently, migration becomes classified as trafficking and any woman going to work in India is assumed to be entering the sex trade. Interventions based on these assumptions tend to take a welfare-oriented top-down approach in which the organization purports to know what is best for Nepali women. This does not take into account the hardship of rural women's lives, which may make migration a key livelihood strategy. Other organizations have adopted a bottom-up, empowerment-oriented framework that aims to protect and promote women's rights, including the right to migrate and the right to do so safely without being trafficked. This approach has yet to be fully accepted or put into operation, however, and NGOs and others working in this area require support to do so.

\section{Trafficking Prevention}

Organizations that conduct prevention programs in rural areas do so either as onetime mass sensitization activities or as part of broader community development or women's rights initiatives that include forming women's groups. The groups associated with the latter approach are then used as a support system and to promote change at the local level. However, most awareness raising efforts use strong antitrafficking messages that merge trafficking concerns with sex work issues. These messages use fear to prevent women from leaving their homes, rather than giving practical advice on decision-making in difficult circumstances. Some organizations also associate trafficking with contracting HIV without regard for the stigma that this may falsely create for those who migrate.

A major gap in preventive interventions (both in content and activities) is the lack of advice and support to rural women on how to migrate safely and a lack of support to female migrants once they reach their destination. This is particularly pertinent since anecdotal evidence suggests that an increasing number of women are being trafficked from their urban workplaces. However, interventions in urban areas are difficult, due to the highly mobile and heterogeneous migrant workforce. Such interventions could benefit from lessons learned in other fields that work with similar populations (e.g., HIV/AIDS and child labor).

Border-based prevention focuses on intercepting suspected trafficking victims at the Indo-Nepal border. This strategy requires careful evaluation to ensure that the right to mobility is not inadvertently compromised.

There is a lack of monitoring, evaluation or documentation of current trafficking prevention interventions. Presently, the success of interventions tends to be judged on whether or not women leave their villages. NGOs need support to develop more 
appropriate impact and process indicators. Given the lack of knowledge about female trafficking and migration, formative research may be required to determine ways in which effectiveness or impact can best be measured. 


\section{Care and Support of Trafficked Women/Girls}

Care and support programs focus on assisting women and girls intercepted at the Indo-Nepal border and those rescued from Indian brothels. When 124 girls were returned from India to Nepal in 1996, the NGOs that assisted them gained considerable experience in this field. Care and support programs primarily aim to return girls and women to their communities, but acknowledge that not all of them want to or can return. Most programs provide these girls and women with counseling and vocational skills. Many of the welfare-oriented programs tend to be prescriptive, telling girls what they should do, advising them to return home and advising families to accept them back. Family assessment appears to be insufficient or ad hoc. There is little emphasis on exploring a girl's feelings or working through family problems. The vocational training tends to be very traditional skills, such as sewing or knitting.

By contrast, empowerment-oriented programs offer girls a range of options and are making efforts to expand vocational training into non-traditional sectors. These programs aim to build self-confidence and facilitate independent living, but acknowledge that this is extremely difficult in the present Nepalese context. Options are very limited for girls who cannot return home. Most are presently living longterm in residential homes.

Current care and support activities have not been adequately documented or evaluated. More information is required to assess lessons learned and to develop effective strategies. NGOs require support to develop innovative approaches that boost independence and self-esteem, especially for women who cannot return home. There is a critical need to develop an alternative to life-long residence in a home. One NGO segregates HIV positive girls from others. These girls are sent to live in a 'hospice' in a remote district. This strategy has no public health justification and warrants careful evaluation.

\section{Networking and Advocacy}

Three different networks in Nepal focus on preventing trafficking: Alliance Against Trafficking in Women and Children in Nepal (AATWIN), National Network Against Girl Trafficking (NNAGT), and Children At Risk (CAR). The first two have ideological differences that result in conflicting messages about trafficking being given to the public and policy-makers and a duplication of activities. Efforts are required to help the various networks unite and develop a common platform. An emphasis on the protection of human rights (as opposed to debating the moral rights and wrongs of sex work or migration) may assist in bridging current ideological gaps. Likewise, networking and advocacy activities need to be coordinated to avoid unnecessary duplication or confusion. Donor agencies in particular should take greater care to assess the NGO programs and need for coordination before committing funding to particular activities. 


\section{Conclusions and Recommendations}

Although a great deal of admirable anti-trafficking work is being conducted in Nepal, there is a need for:

- Systematic research on female migration and trafficking to inform interventions;

- Conceptual clarity on the differences between trafficking, migration, sex work and their relationship to human rights issues.

- Systematic documentation, monitoring and evaluation of interventions and approaches.

- Greater focus on promoting safe migration, addressing urban trafficking and supporting female migrants at their destination.

- Support to NGOs to develop and improve current care and support strategies, especially in counseling, family assessment, appropriate care of HIV-positive girls, and long-term support for women and girls who do not return home.

- Coordination and consistency in advocacy work.

The lack of evaluation and documentation of existing programs makes it difficult to assess their relative effectiveness or potential for sustainability. Even so, the evidence from this research, and experience from other sectors, suggests that programs that are empowerment-oriented, community-oriented, bottom-up and human rights-based hold the greatest promise for the promotion and protection of the rights of women and girls, and, hence, for stopping trafficking. 


\section{Contents}

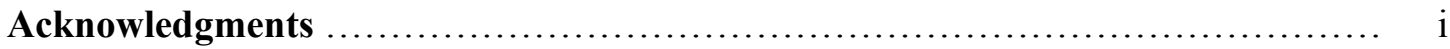

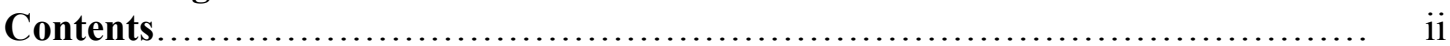

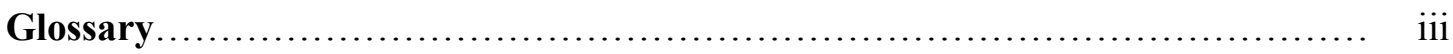

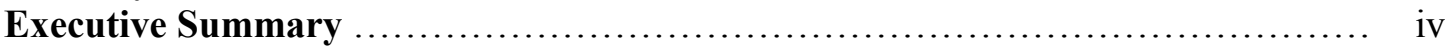

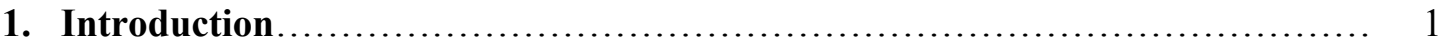

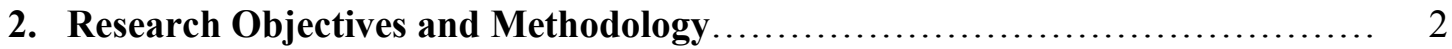

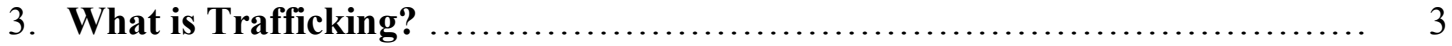

3.1. Trafficking and Migration.............................................. 4

3.2. Trafficking and Sex Work.............................................. 4

3.3. Trafficking in Women and Children ...................................... 6

3.4. Trafficking and HIV ....................................................... 7

3.5. A Matter of Emphasis: Safe Migration .................................. 8

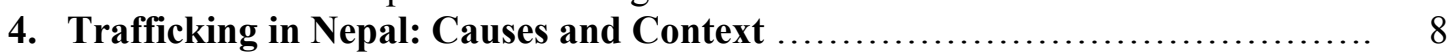

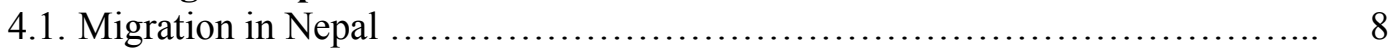

4.2. The Extent of Trafficking in Nepal ..................................... 9

4.3. Trafficking/Migration Processes for Women/Girls in Nepal.................. 9

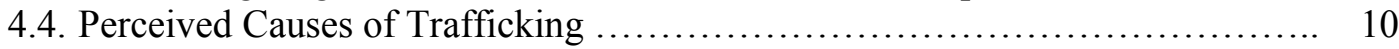

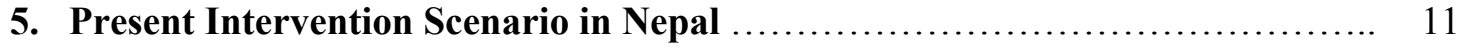

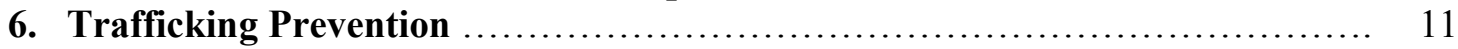

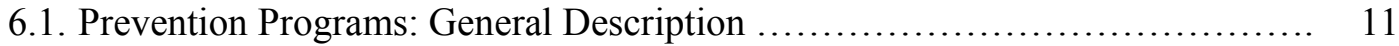

6.2. Conceptual Clarity ................................................... 13

6.3. Targeting 'At Risk' Groups .......................................... 14

6.4. Rural Areas .......................................................... 14

6.4.1. Awareness-Raising, Advice Giving and Social Mobilization ............ 14

6.4.2. Improving Rural Livelihoods through Income Generation/Credit/

Vocational Training ........................................... 19

6.5. Urban- and Workplace- Based Programs ............................... 20

6.6. Border-Based Prevention Programs ................................... 21

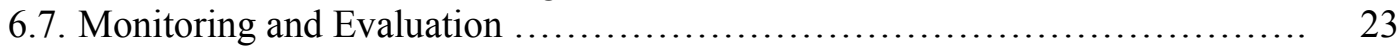

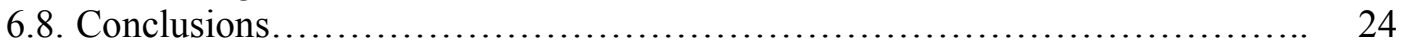

7. Care and Support.......................................................... 24

7.1. General Description of Current Care and Support Programs for Trafficked Girls 25

7.2. The Aim of Care and Support: Conceptual Clarity........................ 26

7.3. Returning Girls to Their Families: Current Practices ....................... 27

7.4. Girls Who Do Not/Cannot Return Home: Current Practices .................. 28

7.5. Rescue and Interception Strategies ...................................... 29

7.6. Care and Support of Girls who are HIV Positive: Current Strategies .......... 29

7.7. Legal Assistance .................................................... 30

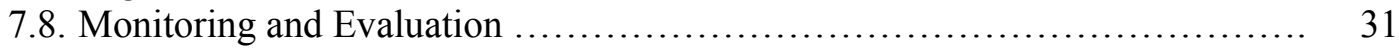

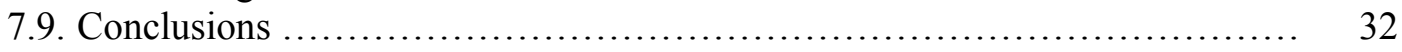

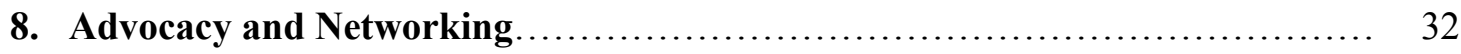

9. Key Findings, Gaps and Recommendations ........................... 33

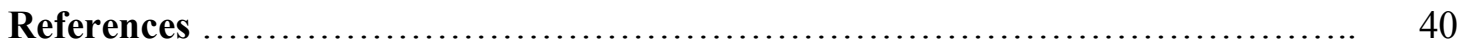

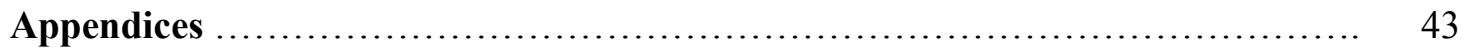




\section{Glossary}

$\begin{array}{ll}\text { AATWIN } & \text { Alliance Against Trafficking in Women and Children in Nepal } \\ \text { ATSEC } & \text { Alliance Against Trafficking and Sexual Exploitation of Children } \\ \text { BCC } & \text { Behavior Change Communication } \\ \text { CAR } & \text { Children At Risk (Network) } \\ \text { CATW } & \text { Coalition Against Trafficking in Women } \\ \text { CWIN } & \text { Child Workers in Nepal Concerned Centre } \\ \text { DDC } & \text { District Development Committee } \\ \text { GAATW } & \text { Global Alliance Against Trafficking in Women } \\ \text { HMG/N } & \text { His Majesty's Government of Nepal } \\ \text { IEC } & \text { Information, Education and Communication } \\ \text { INGO } & \text { International Non-Governmental Organization } \\ \text { MOWCSW } & \text { Ministry of Women, Children and Social Welfare } \\ \text { NGO } & \text { Non-Governmental Organization } \\ \text { NNAGT } & \text { National Network Against Girl Trafficking } \\ \text { VDC } & \text { Village Development Committee } \\ \text { WOREC } & \text { Women's Rehabilitation Center }\end{array}$




\section{A Comparative Analysis of Anti-Trafficking Intervention Approaches in Nepal}

\section{Introduction}

This report analyses the different approaches adopted by NGOs and NGO networks to address the problem of trafficking in women and children in Nepal. In the last decade, both the scale of trafficking in Nepal and public awareness about the problem has increased. The year 1996 was particularly significant when 124 Nepali women and girls were rescued from brothels in Mumbai and placed in Indian remand homes. In the face of inaction from the Indian and Nepali governments in helping these persons, a group of seven concerned NGOs based in Kathmandu organized their repatriation and subsequent care (ABC Nepal 1996; Pradhan 1996). Their action was accompanied by a great deal of media interest, especially when a number of the girls were forcibly tested and found to be HIV positive. Challenged by the task of how best to help these girls, and galvanized by the life stories they recounted, many of these NGOs and others have subsequently developed anti-trafficking programs. Various international donor agencies have supported these anti-trafficking programs, which have become a high priority issue for many donors. The HIV pandemic has also added a sense of urgency to the problem since the social and economic processes underlying trafficking are in many ways similar to those fueling the spread of HIV (AIDS Action 1998; UNDP 2000).

The causes, processes and outcomes of trafficking are complex and subject to considerable debate (Coomaraswamy 1997). Many divergent opinions have been expressed on what the word 'trafficking' really means (Coomaraswamy 1997). Using a human rights framework, the initial sections of this report examine this complexity and discuss the potential implications of differing perceptions for anti-trafficking interventions. The subsequent sections examine how, in the Nepali context, perceptions of trafficking have shaped different intervention approaches. ${ }^{1}$

In spite of considerable anti-trafficking activity in Nepal, there has been very little documentation, monitoring or evaluation of the effectiveness, feasibility or sustainability of current intervention approaches. Existing interventions have been reviewed many times as part of broad-brush anti-trafficking strategy development activities, but their individual components have rarely been examined in depth. Given the likelihood of increased funding for anti-trafficking work, a thorough understanding of how different approaches may (or may not) be working, what lessons have been learned and which areas require further indepth study is crucial. This report represents an initial attempt at this kind of analysis.

\footnotetext{
${ }^{1}$ A complementary report entitled "Trafficking in Nepal: An Assessment of Laws and Policies for the Prevention and Control of Trafficking in Nepal" examines the policy and legal context of the trafficking debate in Nepal.
} 


\section{Research Objectives and Methodology}

The overall objective of the study was as follows:

To document and analyze current intervention models for the prevention of trafficking, and the care and support of trafficked persons.

During August and September 2000, the researchers interviewed key organizations and individuals who are involved in anti-trafficking activities in Nepal (see Appendix 1 for a list of informants). These included one donor agency that has been involved in funding NGOs and in developing anti-trafficking strategies in Nepal, and four other key informants selected because of their extensive knowledge and experience in anti-trafficking work in Nepal. In addition, eight NGOs and two INGOs were interviewed, and key project documents and IEC (information, education and communication) materials were reviewed. The work of the two Nepal-based anti-trafficking networks, Alliance Against Trafficking in Women and Children in Nepal (AATWIN) and National Network Against Girl Trafficking (NNAGT) was also considered.

The selected organizations were chosen to reflect different approaches and focuses so that a comparison could be made. The selected organizations are also the five NGOs that are currently taking the lead on anti-trafficking work in Nepal. These organizations address trafficking in different ways - some as a stand-alone issue, and others as an issue incorporated into other programs (see Figure 1).

\section{Figure 1: Organizations Interviewed for the Report}

\begin{tabular}{|l|c|c|}
\hline Primary Organizational Focus & $\begin{array}{c}\text { Number of NGOs } \\
\text { Interviewed }\end{array}$ & $\begin{array}{c}\text { Number of INGOs } \\
\text { Interviewed }\end{array}$ \\
\hline Child Rights and Welfare & 1 & 1 \\
\hline HIV Prevention & 1 & \\
\hline Legal and Human Rights & 1 & \\
\hline Trafficking as a Stand-alone Issue & 2 & 1 \\
\hline Rehabilitation of Trafficked Girls & 1 & 2 \\
\hline Community Development/Women's Empowerment & 2 & \\
\hline TOTAL & 8 & \\
\hline
\end{tabular}

The focus of the research is to understand the perceptions of trafficking and the assumptions that explicitly or implicitly inform different types of intervention approaches. Therefore, no attempt was made to base the analysis on a representative (random) sample of all interventions currently underway.

Intervention approaches were assessed from a human rights perspective, bearing in mind the conceptual issues underlying the trafficking debate. The analysis looked at issues of coverage, feasibility, sustainability and effectiveness. Lessons learned so far, and key issues to consider for future work, are pointed out.

Intervention approaches were assessed both in terms of content (e.g., what kind of antitrafficking messages or advice were they giving out?) and in terms of process (e.g., how was a particular approach put into operation?).

The results of the research have been categorized under three main headings: 
1. Trafficking Prevention

2. Care and Support of Trafficked Women/Girls

3. Advocacy and Networking

The section on 'Trafficking Prevention' has been further sub-divided into the three sites where anti-trafficking organizations are working: rural, urban and border. Each site raises different issues and involves different approaches and target groups. Likewise, the section on 'Care and Support' has been sub-divided to assess interventions for girls who return home, for those who do not or cannot return home and for those who are HIV positive. Issues pertaining to monitoring and evaluation and specific recommendations are also discussed in each section. Figure 2 shows the report structure.

Figure 2: Analysis of Anti-Trafficking Programs

\begin{tabular}{|l|l|}
\hline 1. Trafficking Prevention & $\begin{array}{l}\text { Rural-based Interventions } \\
\text { 2. Carban-based } \\
\text { 2. Border-based }\end{array}$ \\
\hline & $\begin{array}{l}\text { Girls Who Return Home } \\
\text { - Girls Who Do Not/Cannot Return Home }\end{array}$ \\
\hline 3. Networking and Advocacy & $\begin{array}{l}\text { Rescue and Interception } \\
\text { Legal Assistance }\end{array}$ \\
\hline & $-\quad$ General Comments and Analysis \\
\hline
\end{tabular}

\section{What is Trafficking?}

It is generally agreed that trafficking involves a two-step process: the movement of a person to a site of work, and the subsequent extraction of that person's labor. If exploitation, coercion, deception or abuse of that person's human rights occurs along the way, that person has been trafficked. Accordingly, the UN Special Rapporteur on Violence against Women has defined trafficking as follows (Coomaraswamy 1997):

Trafficking in persons means the recruitment, transportation, purchase, sale, transfer, harboring or receipt of persons:

by threat or use of violence, abduction, force, fraud, deception or coercion (including the abuse of authority) or debt bondage, for the purpose of:

placing or holding such person, whether for pay or not, in forced labor of slavery like practices, in a community other than the one in which such person lived at the time of the original act described.

Trafficking, as defined above, may involve a number of different processes. This is important in understanding the links between trafficking and related concepts such as legal or illegal migration and sex work. 


\subsection{Trafficking and Migration}

Migration is commonly understood to involve the voluntary movement of persons within or across borders in search of a better means of livelihood. However, migration can become linked with trafficking in two ways. Firstly, a person may voluntarily choose to migrate but may be deceived about the kind of work they are subsequently expected to do. In this case, what started as migration has become trafficking. Secondly, a person may willingly migrate for employment but may be trafficked on from the initial employment site (e.g., a carpet factory). The initial process was not trafficking and no crime was committed until the second process of migration occurred. Hence, while trafficking normally involves migration, migration does not always involve trafficking. This distinction is significant for potential anti-trafficking interventions. Given that trafficking may occur either in a person's original home base (often a rural community) or in a subsequent work-site (often an urban area), interventions should cover BOTH locations. Interventions should also recognize that in each site, the factors that create the need or desire to migrate and the vulnerability to being exploited in the process might be quite different.

Likewise, it is important that anti-trafficking interventions consider their direct or indirect impact on a person's right to mobility. Anti-trafficking interventions can easily (and sometimes inadvertently) become anti-migration interventions. However, it is difficult to distinguish voluntary migration from trafficking at the departure point since the deception, if present, has not yet become apparent. It is only after arrival at an unexpected and exploitive outcome that the crime of trafficking is revealed.

Both of the major international anti-trafficking networks, the Global Alliance Against Trafficking in Women (GAATW) and the Coalition Against Trafficking in Women (CATW), agree that interventions should primarily focus on addressing the abuse of human rights occurring during migration or at the workplace rather than on hindering migration per se:

"With the traditional subsistence culture no longer a viable means of livelihood, women often migrate for their own survival. It is therefore imperative that a woman's right to mobility not be impinged upon but rather that the human rights of those who choose to migrate be secured" (WOREC/CEDPA 1999:41).

Another distinction arises with respect to legal and illegal migration. Where legal migration across borders is not possible (e.g., because people lack the relevant documents or where the process of obtaining these is inaccessible to the poor and illiterate), people may migrate illegally. If these persons are trafficked and subsequently intercepted by state authorities, the focus is usually upon their status as illegal migrants rather than as trafficked persons and the crimes committed against them go un-redressed. As pointed out by WOREC/CEDPA (1999:41):

"a holistic approach must be taken to focus upon the social, economic and political circumstances that force a woman to migrate instead of targeting her as a criminal and blaming her for the discrimination she faces." 


\section{$\underline{3.2}$ Trafficking and Sex Work}

Trafficking in women and children is often assumed to be trafficking into prostitution. This assumption needs to be challenged. Evidence shows that women and children are also trafficked into other sectors of the informal economy, such as domestic work or factory work (Sattaur 1993). Sexual exploitation is a common experience for many trafficked (and nontrafficked) persons, but a conceptual distinction needs to be made between this kind of abuse occurring in a variety of settings and involvement in organized sex industries. Nonetheless, though accurate statistics are hard to come by, it is known that many women and children are trafficked for the purpose of prostitution.

Two different issues have tended to frame the trafficking and prostitution debate. The first concerns the distinction between women and children entering prostitution. This issue emerges as an important point within the trafficking debate more generally and will be discussed separately in Section 3.3. The second issue refers to a debate about whether or not it is possible for women to enter the sex trade 'voluntarily' and, even if they do, whether sex work per se is an abuse of women's rights. Within this latter debate, three main positions can be identified.

The first position is represented globally by the Coalition Against Trafficking in Women (CATW), and finds expression among activist groups or networks in many countries, including Nepal. This position proposes that prostitution is inherently degrading to women and that, ideally, sex work should be abolished. Both trafficking and prostitution per se are seen as an abrogation of women's rights and a violation of their dignity. However, more recent declarations by CATW are framed within a human rights paradigm and recognize the difficulties of eliminating prostitution altogether. Hence, while eliminating prostitution remains a long-term goal, CATW also strongly stresses the need to:

\section{"provide rights and protections for women in conditions of sex trafficking and prostitution” (CATW 1999:1).}

The second position is represented by the Global Alliance Against Trafficking in Women (GAATW) and allied groups and takes the view that adult women have the right to choose to engage in sex work:

"it is not prostitution that the anti-trafficking framework opposes but the violation of rights that may occur while involved in that work. Although a woman may enter into prostitution by choice, she does not choose the exploitative conditions she is forced to endure. It is therefore the exploitative conditions and not the sex work itself that need to be targeted" (WOREC/CEDPA 1999:24).

Though these positions appear to be at odds, they do both agree on the need to address the exploitative conditions inherent in many sex trades and to protect the rights of women involved in sex work.

The result of the debate between the CATW and GAATW positions is that both organizations use the term trafficking to refer only to forced prostitution. In recent years, however, a third position has crystallized. This position challenges the dichotomy between forced and voluntary prostitution, and questions the usefulness of the trafficking discourse with respect to sex work. Advocates of sex workers' rights organizations who point out that 
focusing upon forced prostitution may in fact set up and reinforce the traditional 'Madonna/whore' dichotomy within the category 'prostitute' (Kempadoo and Doezema 1998). The Madonna is the innocent 'victim' of trafficking whereas the whore is the guilty so-called voluntary prostitute. Hence, while various international conventions now acknowledge the need to protect the rights of trafficked prostitutes, ${ }^{2}$ not a single convention promotes the rights of all women involved in sex work. Indeed, many states place the distinction between guilty and innocent women at the heart of their legislation on prostitution and trafficking. In Germany for example, the penalty for trafficking is reduced in cases where the person knew she was going to be a prostitute. Likewise, in countries such as Colombia, Uganda, Brazil, Canada, and Japan, legislation exists whereby the use of violence to force a person into prostitution is only prohibited in cases where the woman concerned is of 'undisputed virtue' (Doezema 1998:45).

As Frederick (1998) points out, the process of entry into sex work is often a complex one, where, in reality, the distinction between trafficking and consensual entry may be extremely blurred. It may be the same set of social, familial and economic circumstances that lead women to choose to enter sex work, or to choose to migrate (and perhaps end up trafficked). Even where women enter sex work by 'choice' they may not know beforehand exactly what this work entails and may be unprepared for its exploitative nature. Once involved, however, they may become embroiled in the same processes of slavery-like conditions or debtbondage as trafficked women and are as unable to escape as the latter. Conversely, women who are originally trafficked into sex work, may, after some time, conclude that this represents a profitable livelihood strategy and may not necessarily wish to be 'rescued.'

Within a human rights framework, it is morally impossible to distinguish between women who 'deserve' protection and those who do not. Abuse is abuse. Anti-trafficking interventions should respect the wishes and human rights of women in prostitution (however they got there), and any exclusive focus upon 'trafficked women' should not inadvertently worsen the situation for others.

\subsection{Trafficking in Women and Children}

Within trafficking discourses, the situations of women and children are often discussed together. Likewise, in trafficking statistics, the age range of trafficked women may be as extensive as 12 to 29 years with little recognition of the difference between adult women and teenage children (Doezema 1998). The result is that women are infantilized and represented as having little agency and as being in need of paternalistic protection. Interventions clearly need to distinguish between the two groups and to recognize an adult woman's right to make her own decisions even if this includes, for example, deciding to engage in sex work. By contrast, there is international agreement that child trafficking and child prostitution of any kind is a violation of that child's rights and is a crime. By implication, children should be removed from exploitative situations and provided with help and support without question (Acharya 1998).

The nature of this help and support must be considered from the perspective both of the cultural context of childhood and child labor and from the child's own perspective. In countries such as Nepal, for example, the vast majority of children live in poverty and are

\footnotetext{
${ }^{2} 1992$ Convention for the Elimination of Violence Against Women; 1993 World Conference on Human Rights; 1995 Beijing World Conference on Women (quoted in Doezema 1998:40).
} 
expected to assume a range of work-related responsibilities within or outside the home from an early age (Panter-Brick 2000; Jenks 1996; Save the Children/UNICEF 2000). In addition, many children are married and sexually active by the time they reach sixteen (the legal age of majority in Nepal). Hence, the appropriate response to a so-called 'voluntary' prostitute aged 16 or 17 is perhaps not as clear-cut as child rights conventions appear to suggest. Research on street children and child workers indicates that even where children are concerned, there often exists an initial wish to migrate or to run away from difficult circumstances and, as with adults, trafficking may (or may not) occur in the process (Baker and Panter-Brick 2000). Hence it is important for interventions to recognize a child's agency in trying to escape from, or improve upon, their situation and to seek their participation in developing appropriate solutions (Baker and Panter-Brick 2000). Even where children have been put to work by their parents, this again may represent a household survival strategy and, while not compromising the rights of the child, interventions must consider their impact upon the household as a whole (Montgomery 1998, 2000).

\section{$\underline{3.4 \text { Trafficking and HIV }}$}

The most frequently highlighted association between trafficking and HIV is the increased likelihood of HIV infection in women and children trafficked for purposes of prostitution. Rates of HIV infection among sex workers range from 21 percent in urban areas in Nepal to as high as 72 percent in Mumbai, India (UNAIDS 2000). Although no data are available on rates of HIV among trafficked women and children, it is reasonable to conclude that those trafficked for prostitution would assume the same prevalence of HIV as the sex workers in the area in which they are held depending on their length of stay. In addition, their rate of HIV may be even higher since they are less likely to protect themselves with condoms. They are less likely to be beneficiaries of sex worker interventions and empowerment movements due to their forced working conditions and debt bondage.

Even those women and children who are not trafficked into prostitution are subject to sexual abuse and are therefore at increased risk of contracting HIV. Trafficked women and children are not able to control even the most basic aspects of their lives, least of all to negotiate safe sexual relations. Displacement from family and community support systems, language barriers, vulnerability, and subsequent risk of HIV infection are increased (UNDP 2000). In addition, those who are trafficked internationally are classified as illegal immigrants in their country of destination and are further marginalized with less access to education, services, and protection. If they seek help, they may be subject to prosecution for the crime of illegal immigration, rather than assisted as a victim of trafficking.

Highlighting the link between trafficking and increased HIV risk may not be in the best interest of returned trafficked persons since it may result in increased stigma for returnees. In the past, women who left sex work could reintegrate into their communities with relatively few problems, especially if they returned with some wealth. However, the current panic associated with the AIDS epidemic in Nepal is such that women returning from a big city in India are stigmatized as carriers of HIV, regardless of whether they have been engaged in sex work. 


\subsection{A Matter of Emphasis: Safe Migration}

The previous discussion indicates that processes of migration involve particular risks for women and children. These include the risk of being trafficked into an exploitative situation (including but not limited to the sex trade); the risk of being sexually exploited; the risk of contracting HIV and other health problems and of being labeled an HIV carrier. Short of preventing migration altogether, it is apparent that the primary issue is not necessarily trafficking, but, rather, how to make migration safe for women and children and how to protect their rights prior, during and subsequent to migration. In many cases, women and children might see no choice but to migrate, even though they would prefer to stay at home. In these situations, strategies need to be developed to enhance social and economic opportunities in the rural areas. These issues require a great deal more research to develop a clearer understanding of the motivations and processes involved.

\section{Trafficking in Nepal: Causes and Context}

\subsection{Migration in Nepal}

Data on migration, especially female migration, for the 22.6 million people who live in Nepal is extremely sparse. However, a recent report notes how, as income from agriculture is decreasing, migration is playing an increasingly important part in Nepal's economy and in people's livelihood strategies (Seddon et al 1999). In a context where almost 95 percent of the population still live in rural areas (1997 Census), the report found that on average onequarter of all rural households receive remittances and that this source of income accounts for as much as one-quarter of total household income. In some areas, notably the Western region, up to one-third of households receive remittances with the majority of these coming from India or from other places within Nepal (NLSS 1995/6). Another recent report on migration in Doti District (in Nepal's Far West) found that 49 percent of households had a family member in India (Poudel 1999).

However, it was only in the 1998 Ninth Plan of His Majesty's Government of Nepal $(\mathrm{HMG} / \mathrm{N})$, that the significance of migration was officially recognized as a national issue. The report points out that:

"even now, however, the scale and significance of the phenomenon appear not to have been appreciated by national policymakers or politicians (or, indeed by the major bilateral and international development agencies), and there is no coherent program to increase the benefits of the remittance economy or to reduce the very real social cost of foreign labor migration as part of Nepal's overall development strategy" (Seddon et al 1999).

The report by Seddon et al (1999) makes a very conservative estimate that approximately 25 percent of Nepal's GDP is from foreign remittances (not including those from within the country). Approximately 660,000 Nepalese are officially recorded as working abroad (mainly in India). This accounts for approximately six percent of the active labor force, and compared with other countries in the region, this figure seems unrealistically low. However, this figure includes only registered migrants and the actual number is estimated to be much greater. 
These statistics have been presented to show how migration plays a major role in Nepal's economy and is an issue that requires attention. It is not clear, however, to what extent this migration involves women. The report by Seddon et al (1999) found that 23 percent of registered migrants were women, but suggests that the great majority of female migrants are likely to be unrecorded because female labor is mainly concentrated in the informal, unregulated economic sectors. However, the study in Doti estimated that only one percent of migrants were women (Poudel 1999). A district-based analysis of female migration is clearly necessary to shed more light on women's movements within and outside Nepal.

\subsection{The Extent of Trafficking in Nepal}

It is extremely difficult to estimate the number of Nepalese women and children who have been trafficked. The difficulties arise partly because of a lack of reliable research in this area, and because of the difficulties described above of defining what trafficking is and at what stage along the migration path it occurs.

Certain figures have become accepted as conventional wisdom, but in reality, they are out of date and were unsubstantiated in the first place (Sanghera 2000). These figures refer only to women and girls trafficked into the sex industry. These include estimates that between 100,000 to 200,000 Nepali women are working in the Indian sex industry, and that between 5,000 and 8,000 young women are trafficked for prostitution into India each year. Many figures are prone to exaggeration. For example, one report notes that the "majority of the 40,000 prostitutes in Sonagachi (a red light area in Calcutta) are Nepali" (Pradhan 1996:34). Based on more reliable research, it is now known that there are in fact only a total of 12,000 sex workers living in Sonagachi and that the vast majority are Bengali (AIIHPH 1993). This is not to deny that Nepalese women and girls are to be found in many Indian red light areas. However, experts suggest that it is probably the case that a greater number of migrant Nepali women are employed in other sectors - including the industrial, construction, transport, hotel, restaurant and domestic service sectors - both in Nepal and abroad, rather than in commercial sex work (Seddon et al. 1999; Sanghera, personal communication).

\section{$\underline{4.3 \text { Trafficking/Migration Processes for Women/Girls in Nepal }}$}

The discussion below on trafficking and migration processes is based on the observations and reports of NGOs in Nepal who are active in the anti-trafficking field (Rajbhandari 1996; Pradhan 1996; ABC Nepal 1996; Acharya 1998). These valuable observations are based on field-level experiences. However, systematic, comprehensive, and reliable research in this area is lacking.

Reports from women who have been trafficked suggest that, as in the case of men (Seddon et al, 1999), trafficking or migration operates through personal connections and social networks. For example, an aunt returns to the village and takes a niece back to the city with her. It also operates through unregistered brokers who may or may not be strangers to the locality. In terms of trafficking, neither source is 'risk free.' Women and girls are reportedly attracted by reports of wealth and fun in the city, and are apparently easily 'duped' into trusting the mediator. Likewise, some women are deceived into false marriages with the broker and are subsequently sold into the sex industry. It has been suggested that brokers are increasingly operating within organized trafficking networks. These brokers are said to be covering large tracts of Nepal and are developing increasingly sophisticated methods. For example, it is apparently becoming increasingly common for trafficking to take part in 
stages, with women moved around to work in different sites before finally being sold into sex work. Carpet factories in Kathmandu are known to be common transit points. However, further research is required on the extent to which trafficking is organized through formal networks, and the exact methods used.

The extent of familial involvement in trafficking is cause for much controversy in Nepal. In certain communities (such as the Badi and the Deuki), sex work is a customary practice and continues to this day. In other communities in a few districts, notably Nuwakot and Sindupalchowk, there has likewise been a tradition of sending girls to 'service' the ruling classes in Kathmandu that, in time, has changed into involvement in commercial sex. In these communities, female involvement in sex work is common knowledge and an important source of income. In most cases, however, it is suggested that though parents may sanction a daughter's migration and may even accept money in advance for her labor, they do not fully understand her risk of entering the sex trade (or of otherwise being exploited). Likewise, parents may accompany daughters to the carpet factories in Kathmandu but may not be aware of, or involved in, any subsequent trafficking.

\subsection{Perceived Causes of Trafficking}

There is consensus among groups, internationally and within Nepal, that female trafficking is a complex multi-causal phenomenon (O’Dea 1993; Acharya 1998; ILO/IPEC 1998; ABC Nepal 1996; Rajbhandari 1996; Sanghera 2000). At the local level, trafficking involves deeprooted processes of gender discrimination, lack of female education, ignorance and naiveté of rural folk, poverty and lack of economic opportunities in rural areas, with consequent marginalization of particular social groups. These processes are influenced by macro-level economic and social changes that are altering marketing traditions and labor requirements. These factors, combined with modern marketing techniques, are also changing (and perhaps unrealistically raising) people's fundamental expectations of life and what 'basic needs' are. While some of these proposed causes can be said to increase vulnerability specifically to trafficking (e.g., women's lack of empowerment or lack of information about what may happen if they migrate), the rest are part of changes happening globally that are leading both to the increased feminization of poverty and to increased female migration. Hence, they are factors that lead to the desire or need to migrate. Again, it is perhaps misleading to single these factors out as being fundamental causes of trafficking per se. Rather, these factors underlie the phenomenon of increased migration, with some people being trafficked as a result.

The nature of the vulnerability to being trafficked (as opposed to migrating safely) has not been explored in any depth in Nepal. Dominant representations of trafficked 'victims' in Nepal usually depict a happy, innocent, and naïve village girl who is suddenly tricked or kidnapped by a stranger and sold into sexual slavery. Some authors (Frederick 1998; Frederick and Kelly 2000) have challenged this picture as a myth and challenge the assumptions of village and family life underlying many representations of trafficking. Their work and the little research that exists seem to indicate that many (though not all) women are trafficked by people known to them. Like other women in prostitution, many of those who are trafficked into the sex trade come from disturbed and difficult family circumstances, such as divorce; alcoholism; sexual, physical or emotional abuse; or death of a bread winner (Sanghera 2000; ABC Nepal 1998; Pradhan 1996). Therefore, they may lack crucial social supports and may be particularly desperate to change their situation. 
Other factors that create an environment conducive to trafficking in Nepal are said to be the open border between India and Nepal, inadequate political commitment to address trafficking, and a failure of the police and judiciary to enforce existing laws. It was not until 1995 that HMG/N formed a Ministry of Women, Children, and Social Welfare (MOWCSW) with trafficking as one of its mandates.

\section{Present Intervention Scenario in Nepal}

Because of a workshop in 1998, His Majesty's Government of Nepal developed an antitrafficking National Plan of Action (MOWCSW 1998). Existing and planned anti-trafficking activities were categorized under the following six headings:

1. Policy, research and institutional development

2. Legislation and enforcement

3. Awareness creation, advocacy, networking and social mobilization

4. Health and education interventions

5. Income and employment generation

6. Rescue and reintegration

Twelve international agencies are providing support to the government and NGOs to develop and expand anti-trafficking activities in these areas.

It is difficult to assess how many NGOs are directly or indirectly involved in anti-trafficking work in Nepal. Many NGOs became involved in 1996 to help with the girls who were returned from India. Not all are still directly involved with trafficking issues though they may serve as referral points for other agencies that are. The two anti-trafficking networks, National Network Against Girl Trafficking (NNAGT) and Alliance Against Trafficking in Women and Children in Nepal (AATWIN), have at least 35 organizational members. A 1996 survey of NGOs identified 16 Kathmandu-based NGOs that were directly involved in antitrafficking work (CFD 1996).

\section{Trafficking Prevention}

\subsection{Prevention Programs: General Description}

This and the following section present a general description and analysis of the different kinds of trafficking prevention programs. Programs in the three different sites (rural, urban and border) are respectively analyzed in more detail in sections 6.3 to 6.5 .

ACTIVITIES: The most significant anti-trafficking activities fall into the following areas;

- Awareness raising, advice giving, and social mobilization.

- Improvement of livelihood opportunities through income generation/vocational training.

- Interception of potential trafficking victims at the Indo-Nepal border.

FOCUS: Interventions are spread among several program focuses (see Figure 1) with two NGOs addressing trafficking as a stand-alone issue and one focusing on rehabilitation of trafficked girls. The current research found that despite the variation in focus and emphasis, there is considerable overlap of process (for example, the strategy of group formation). 
Hence, the discussion below does not examine each intervention individually. Rather, general processes and content are compared.

TARGET GROUP: Interventions work with single or multiple target groups ranging from the politically and economically powerful (e.g., the police, District or Village Development Committee members, employers or community leaders) to the disenfranchised (e.g., low caste or landless groups or city migrants). At the grass roots level, activities are further differentially targeted towards women, children, schools, female migrant workers, or local men. Some interventions in the rural areas specifically target girls who they deem to be at particular risk of being trafficked. Without further research, it is not possible to comment on the effectiveness of targeting and this issue is discussed in more detail below. In general, however, experience in other fields shows that for any kind of social change to take place, all stakeholders must be involved to a greater or lesser extent.

APPROACH: Although there is some overlap, programs can be broadly classified as: (i) those that take a top-down approach with a welfare-orientation and (ii) those that take a bottom-up (or community-based) approach and have an empowerment orientation. The topdown/welfare-oriented programs are generally one-time activities that concentrate on raising awareness, with only minimal follow-up or subsequent community-level support. They tend to be prescriptive (telling people what to do) rather than facilitating a process of informed decision-making. Bottom-up/empowerment-oriented programs tend to be rooted in communities and usually address trafficking in the context of other needs and priorities with empowerment as an overall aim. They also tend to establish community or group support systems to help those in difficult circumstances and to address trafficking from a position of collective strength.

Figure 3: General Description of Prevention Programs

\begin{tabular}{|c|c|}
\hline Program Site & $\begin{array}{ll}\text { - } & \text { Rural areas } \\
\text { - } & \text { Urban workplaces } \\
\text { - } & \text { Indo-Nepal border } \\
\end{array}$ \\
\hline Activity & $\begin{array}{l}\text { - Awareness-raising, advice giving and social } \\
\text { mobilization } \\
\text { - Improvement of livelihood opportunities through } \\
\text { income generation/vocational training } \\
\text { - Interception of potential trafficking victims at the } \\
\text { Indo-Nepal border }\end{array}$ \\
\hline Focus & - Range of organizational foci \\
\hline Target Group & $\begin{array}{l}\text { General Population Groups } \\
-\quad \text { The powerful (e.g., state authorities, elected } \\
\text { representatives, employers, other leaders) } \\
\text { - } \quad \begin{array}{l}\text { The disenfranchised (e.g., women, children, low } \\
\text { caste, landless groups, migrant workers) }\end{array} \\
\text { 'At Risk' Groups } \\
-\quad \text { Women/girls classified as 'at particular risk' of } \\
\text { being trafficked }\end{array}$ \\
\hline Approach & $\begin{array}{ll}\text { - } & \text { Top-down/welfare } \\
\text { - } & \text { Bottom-up/empowerment }\end{array}$ \\
\hline
\end{tabular}




\section{$\underline{6.2}$ Prevention Programs and Conceptual Clarity}

Among the ten NGOs and INGOs interviewed, it was apparent that there is some divergence of opinion on the meaning of trafficking. Three NGOs have adopted a definition rather similar to the United Nations definition described in Section 3:

All acts and attempted acts involved in the recruitment, transportation within or across borders, purchase, sale, transfer, receipt or harboring of a person:

A. involving the use of deception, coercion (including the use or threat of force or the abuse of authority) or debt bondage

B. for the purpose of placing or holding such persons, whether for pay or not, in involuntary servitude (domestic, sexual or reproductive), in forced or bonded labor, or in slavery-like conditions, in a community other than the one in which such persons lived at the time of the original deception, coercion or debt bondage (quoted in WOREC/CEDPA 1999:21)

The other organizations have defined it differently, usually equating it with sex work, for example:

"girls sold into the sex industry against her will"

"a trade involving the buying and selling of girls and women and their movement and transportation for sexual purposes"

Interestingly, the Nepali phrase for trafficking that is used by most organizations in their IEC materials is cheli beti ko bech bikhan (literally, "girls/women being bought and sold").

The latter definitions contrast in important ways with the United Nations definition offered in Section 3 of this report. The United Nations definition argued that trafficking cannot be limited just to sex work, though this is an important part of the problem. An exclusive focus on this alone means that other forms of trafficking are neglected. It may also lead to the assumption that all trafficked women (or even all female migrants) are sex workers. While recognizing the reality that many trafficked women do end up as sex workers, given the stigma associated with sex work in Nepal, the social implications of explicitly encouraging such an assumption needs serious consideration.

In addition, the definitions above do not recognize the dual process (movement and work) that trafficking may involve. The Nepali translation of trafficking stresses the buying and selling aspect, ignoring those processes of trafficking that start with consensual and legal migration. Hence, for example, families who send their consenting daughters to work in a carpet factory in Kathmandu may not feel that a trafficking risk (as defined above) applies to their situation at all. Likewise, families who receive what they believe to be a salary advance for their daughter's labor, may not consider this to be 'selling.' 


\subsection{Targeting 'At Risk' Groups}

This section considers the concept of risk and the appropriateness of targeting prevention programs at girls who are deemed to be at particular risk of being trafficked. Four of the NGOs interviewed for this report run specific programs in rural areas that are targeted at 'vulnerable' girls. Interventions include vocational training or skill building, micro-credit, support for formal schooling or enrollment in special non-formal education classes. To date, none of these interventions has been formally evaluated.

To be effective, targeted programs must be based on a sound understanding of vulnerability or risk. Some key informants questioned whether this was in fact the case. Very little good quality or comprehensive research has been done on this issue, hence present targeting is largely based on common sense, and risk is defined in a rather general, group-based and broad-brush manner. Therefore, for example, current risk 'groups' include low caste women/girls, school dropouts, poor women/girls, unmarried young girls, and those who already have a relative working in Bombay/India. At this time, it is difficult to judge the appropriateness of these kinds of criteria. However, some key informants suggested that they might be too broad. Preventative or risk-based work (with children) in many other countries is targeted on a case-by-case basis towards individual families or households who may have specific problems in addition to more general deprivation. For example, a situation of general poverty may be exacerbated by the presence of an alcoholic family member or an abusive stepparent. It is not clear whether this is also the case in Nepal, but the definition of risk perhaps warrants further research. In particularly difficult family circumstances, it may not always be desirable for the young person or woman to remain in their home. If locallevel solutions or support are not available, it may be necessary for that person to leave the situation. Hence, targeted trafficking prevention work may well require back-up systems and structures for very troubled families or individuals even where this may mean that, in the worst scenario, a person has to leave the home. The research found that most NGOs appeared to judge the success of a program (targeted or otherwise) with the numbers of girls who stayed in the village. Girls who left were assumed to have been trafficked. This approach not only confuses trafficking with migration but also neglects the issue of how best to support those in crisis.

An innovative example of how local level support may operate was given by one NGO that works with women's groups. In cases of severe domestic violence, the affected woman is sent to stay with another women's group in a different village where she is safe until the issue is suitably resolved. In this way, action is taken on a family-specific and problemspecific basis to resolve issues that otherwise may lead women and girls to run away. Approaches such as this deserve further support and analysis.

\subsection{Rural Areas}

\subsubsection{Awareness-Raising, Advice Giving, Social Mobilization}

(A). CONTENT

All organizations were asked about the content of their anti-trafficking messages and IEC materials were reviewed. Five NGOs (out of ten contacted) responded to a request for copies of their materials. These materials are representative of different program focuses and approaches. 
Most interventions attempt to inform local people of what trafficking is and what might happen to girls when they leave the village. All of the IEC materials reviewed equated trafficking with sex work, and used gruesome descriptions of the suffering that sex work involved. Underlying this kind of information giving is the assumption that knowledge will lead to behavior change. In this case, information was generally designed to evoke fear and to act as a deterrent for girls and women who may be tempted to leave their village with a broker. Experience in the field of behavior change communication (BCC) has shown that a negative and fear-based information campaign is usually less effective than one that positively promotes change and that offers concrete solutions relevant to people's lives (King 1999). Fear often leads to denial - "it won't happen to me." Only two organizations included sections in their IEC materials that gave suggestions on how women could improve their situation in the village, though these did not explicitly give advice on what women can do to migrate safely.

The lack of advice on what women can do if they want or need to migrate was a shortcoming of the majority (but not all) of awareness raising activities. Rather than giving such advice and engaging in a dialogue about livelihood options or other problems, many organizations appeared to conduct IEC from a welfare orientation, purporting to tell young women and girls what was good for them, whether or not this matched the local reality. In doing so, most interventions seemed to implicitly assume (and give the message) that all migration led to sex work and, therefore, that women should stay at home. Some were even more explicit. One message urged girls "not to be so modern, work hard, be patient and stay at home." Four issues come to the fore here. The first is that paternalistic, welfare approaches have historically been shown to be ineffective and, at their worst, have generated resistance from local populations, or have driven a problem underground (Brandt 1988; Walkowitz 1980). Second, these messages may have the effect that all migration (or all women who work outside the home) becomes equated with sex work (Walkowitz 1980). As mentioned previously, given the stigma associated with sex work in Nepal, promoting this kind of assumption needs serious thought. IEC materials from two organizations did explicitly encourage tolerance and acceptance of returned trafficked sex workers. While this clearly is also very necessary, it is a different issue. Thirdly, these kind of messages seem to be promoting the status quo and do not provide any help or suggestions for women and children who may be in very difficult circumstances. Finally, they assume that home is a safe and happy place to be, whereas evidence indicates that this is certainly not always the case ( $\mathrm{ABC}$ Nepal 1998). IEC materials from only two organizations depicted a woman's life in rural Nepal as difficult and as leading to a desire for change. Many organizations and related IEC materials appeared explicitly or implicitly to promote a common idea - a girl's extravagant wish for the modern life and for beautiful possessions is a prime motivation for her to leave the village. They seem to suggest that this is wrong. For example, one message was as follows:

"People come to our village and lie and deceive our simple girls. They lure them with hopes of making lots of money."

Again, a character in a very sympathetic and generally well-thought IEC piece comments that:

"ambitious girls usually face this fate as they make irrational decisions." 
The story about the girl in question subsequently revealed that she had in fact been lured away, tricked supposedly by her irrational decisions and ambition into a false marriage.

This leads to the question of how realistic and relevant to women's lives current IEC materials are. Undoubtedly young girls are attracted by stories of the city. This is only natural in young people, especially when their current situation may be one of grinding hard work and poverty. Young people dream and are impulsive. IEC materials need to recognize and build upon this tendency in a positive way rather then giving moral lectures or stories of doom which past experience in other fields has shown to be ineffective (King 1999). Some informants from the NGOs pointed out a paradox. Throughout Nepal, women's empowerment and education activities encourage women to dream and to have aspirations that often cannot be fulfilled in a rural village. There is a fine and very difficult line in BCC between building confidence, maintaining hope and enthusiasm, and being realistic enough to be meaningful.

All but two of the IEC materials reviewed depicted the women and girls as being trafficked by strangers. Again, it is not clear to what extent this actually reflects the reality of the situation in Nepal. While it is always easier to present the threat as being on the 'outside,' such messages fail to help women who may be trafficked by their own families or by others who are known to them. Two IEC pieces did give examples or case studies of girls who were tricked or sold by friends, and, in one case, by a stepfather.

Only three organizations gave advice for women on what to do if approached by someone to leave their homes for work or marriage. The advice included the following suggestions:

- Before marriage, inquire about the family, address, and work of the boy.

- Before starting work, inquire about the full address of the workplace and the employer.

- Guardians should accompany girls to their jobs.

- Before deciding about marriage or taking a job, discuss this with others.

- Be careful of strangers, both men and women.

Giving such advice is extremely important, and at least acknowledges the reality that some women and girls have to (or want to) migrate. Though a first step, this advice in itself may not be enough to safeguard women and girls. In cases where women are trafficked by those known to them, they may trust them and not perceive a risk at all. It is difficult to see how to protect a girl who is trafficked by her own stepfather or by other relatives. In addition, accompanying girls to a workplace, or taking down the address of the workplace may not in itself prevent onward trafficking from the place of work (which, according to the NGOs, is a growing trend in Nepal). For this reason, it is clearly important to give concrete, relevant advice to those thinking of migrating. There also appears to be a crucial need for interventions or support for women and girls at their place of work and in the cities. This is a gaping hole in Nepal's current anti-trafficking strategies, though a few organizations have now begun to address this area (discussed further below). One of the NGOs interviewed noted that it is considering developing a kind of 'information kit' for potential migrants that would include information on what to do in the city if approached by brokers, or if individuals did end up in exploitative conditions. This seems to be a promising approach but would require concrete links with city-based or industry-based organizations that are already involved with, or are willing to get involved with labor rights, women's rights and sex industry issues. 
None of the IEC materials reviewed explicitly referred to city-based or workplace-based trafficking. As mentioned previously, trafficked girls are generally depicted as being sold straight into the sex trade with no in-between steps.

The final point with respect to the content of anti-trafficking awareness raising activities is the connection that some organizations are making between trafficking and HIV. Examples of messages (from three different organizations) are as follows:

- Girls return, their youth destroyed, most come back with AIDS and die.

- Because of trafficking, AIDS in Nepal is increasing daily.

- This crime not only stigmatizes our village, our household, but also our national prestige, because these girls, after being tortured, also bring back AIDS and are destined to die.

- When you send your girls to India, they will not only bring back money but they may also get AIDS.

As described in Section 3.4, the rationale for linking HIV specifically with trafficking is questionable. Though appearing to be common sense, it raises serious questions about notions of HIV risk and the stigma it may create about women who have worked in India, whether or not they were sex workers. According to one NGO, it is already 'common knowledge' among truck drivers and other male clients in Nepal that "India girls" have HIV. These men simply go to other sex workers whom they may quite wrongly perceive to be risk-free. Quite apart from stigmatizing women who have worked in India, these kind of messages create a sense that AIDS is a problem of India (not of Nepal) and that it is somehow the problem of the women concerned rather than of the men who visit them. Moreover, some organizations appeared to suggest that preventing trafficking would greatly help to prevent AIDS in Nepal. Again, while appearing to be common sense and while prevention of trafficking into the sex trade may well avoid some cases of HIV in Nepali women, this does not in itself address the behavior of men or address the vulnerabilities to HIV of non-trafficked female migrants or sex workers.

\section{(B). PROCESS}

In rural areas, organizations have a used a variety of trafficking awareness raising approaches. The main distinction between these approaches is between those that are topdown as opposed to bottom-up (or community-based).

Top-down interventions appear mainly to engage in sensitization programs, aiming to impart mass awareness, rather than working in a more concentrated and small-scale manner with communities to set up support systems that can encourage change. Hence, they tend to involve one-time visits to particular villages or Village Development Committees, holding lectures, seminars, or workshops, and carrying out street dramas or house-to-house visits to inform people about trafficking. Some top-down interventions especially target powerful stakeholders (e.g., police, District and Village Development Committee officials) in the belief that trafficking can only be addressed with the support of local power brokers. After these kind of one-time events, communities are urged to be more vigilant about women leaving the village. One NGO actively encourages locals to report those whom they suspect to be involved with trafficking to the police. At one time, they distributed anonymous reporting cards that local people could fill in and give to the police. Anecdotal evidence suggests that this strategy was misused by the communities, and political rivals apparently 
indiscriminately filled in the names of their enemies and attempted to get them arrested on charges of trafficking (Adhikari 1997, personal communication with key informants). This kind of strategy raises questions about the rights of those accused. Other anecdotal reports suggest that after these kinds of intensive one-time awareness raising campaigns (which are often couched in morally disapproving tones), some families now feel unable to let their migrant daughters come and visit them (or they may be prevented from leaving again, or arrested as a potential trafficker, or simply because they are now stigmatized as sex workers). Apparently, in these places, male relatives now visit their female kin in India instead and receive their remittances at that end (Adhikari 1997). This is a concrete example of how the equation of trafficking with sex work and female migration combined with strong moral censure (typical of a welfare approach) may inadvertently have negative effects on local community relations and on the women and households involved. Apart from these kind of negative effects, the impact on trafficking itself is doubtful. Morality-based campaigns often end up driving the phenomenon underground (Walkowitz 1980). As mentioned above, experience shows that one-time activities with little follow-up or support are unlikely to lead to action and are difficult to sustain. However, more research into the impacts and community responses to this kind of intervention is required.

Some top-down programs in rural areas have enlisted the help of trafficking survivors. In this setting, their help is generally limited to speaking at awareness raising and advocacy events. This rather personalized and peer information-giving undoubtedly helps in making messages more real and relevant to the everyday lives of rural people. However, information giving alone (even from a 'survivor') without any accompanying support structures is likely to have only limited impact.

Bottom-up community-based interventions take a variety of forms. Most focus on forming or working with existing women's groups, recognizing that women are more likely to be able to act for change or resist trafficking collectively rather than individually. In addition, they aim to impart not just information but also to set up community systems and support through which empowered individuals or groups can be helped to take action and to obtain concrete assistance. Most community-based programs address trafficking in the context of a wide range of community needs and priorities and have found that taking a holistic approach is essential to gain community trust and support. For example, one organization formed women's groups specifically around the issue of trafficking but found that they had to expand their activities to cover a whole range of issues that the groups identified as important to them. Hence, most community-based interventions usually include activities around women's legal rights, literacy, income generation, and credit. NGOs note that gaining accurate information about trafficking, or even being able to discuss this openly as an issue within a group, requires several months of relationship- and trust- building.

In addition to working at the grass roots level, community-based interventions (like topdown programs) also simultaneously work with local power brokers (at neighborhood, Village Development Committee and district level) to sensitize them to the trafficking issue and to gain their support. However, it has been found that outside help from the NGOs is still required on a long-term basis in the form of group facilitation or legal expertise. This is especially true when local groups attempt to take a trafficking-related case to court.

One NGO has started to work with groups of men around a theme of "positive masculinity" in which men question their own behavior and are encouraged to support women's 
empowerment. This is a new and potentially innovative approach but has not yet been systematically documented or evaluated.

Most community-based interventions explicitly or implicitly encourage what one NGO has termed 'community surveillance.' The idea behind this is that local groups are sensitized to trafficking, become more vigilant of local affairs and will feel empowered enough to take action in the event of suspicious circumstances. For example, strangers seen leaving the villages with groups of girls may be stopped and brought to the relevant authorities for questioning. A number of NGOs report that this strategy appears to be effective, citing numerous examples where groups intercepted brokers accompanying girls or where they could report that no girls at all left or went missing from a particular locality. At the time of this research, none of these cases appear to have been thoroughly documented. Reports are anecdotal and it is difficult to assess the exact circumstances behind an incident and to assess how many such incidents have occurred in response to interventions. More documentation and monitoring are urgently needed to help assess the relative effectiveness of different kinds of intervention.

Community surveillance appears to be an innovative approach that has some potential for taking action against trafficking at the local level (rather than just raising awareness). However (though there is no evidence as yet for this), this strategy may be open to some abuse unless it is very carefully monitored and facilitated by the relevant NGOs. Here again, the issue is how to distinguish legitimate migration from trafficking and how to detain brokers and potential migrants before any crime has been committed, or even before any evidence of such may be available. Another issue is how to promote the right of women and girls to freely leave their communities (and to do this secretly if they wish) while simultaneously ensuring their protection from exploitation. There are no answers to these dilemmas yet, but a better understanding of appropriate interventions, careful monitoring and evaluation of programs such as this are extremely important.

NGOs described how, in addition to the examples cited above, other local responses to their community-based interventions have been in the form of locally organized rallies or other kinds of locally organized awareness raising programs. Again, the effectiveness of this kind of community action against trafficking has not been determined, though it does indicate a positive sense of community concern about the problem. It is not clear to what extent local people involved in such initiatives are conceptually clear about trafficking vis a vis migration.

Other than working with local women, some community-based initiatives also focus on children or adolescents. Some work through child clubs (which are usually created for general child rights and welfare activities, not just for trafficking) or through local schools. Here again an integrated approach is taken where trafficking is incorporated into other activities. These programs have not been evaluated with specific reference to trafficking. Where they may prove particularly valuable however is through the relatively neutral support system that they create for a young person. If difficulties arise, children can turn to teachers, peers, or NGO staff. This may be particularly important for children living in difficult family circumstances.

An important, but rarely discussed, issue in community-based anti-trafficking interventions is the extent to which initiatives are actually representative of the social, economic, and political structures and divisions that exist in a community. For example, are groups 
representative of all kinds of caste, age, ethnic group, economic group, or household? Are the most vulnerable or marginalized included? Are the support systems that exist prepared to support anyone in trouble or do existing divisions affect the distribution of help? These are questions that some interventions can answer anecdotally and in general terms, but these issues are yet to be fully elaborated in program planning, monitoring or evaluation.

\subsubsection{Improving Rural Livelihoods through Income Generation/Credit/Vocational Training} Community-based (and targeted) interventions generally include some kind of income generation, micro-credit, or vocational training element. Common activities include (but are not limited to) animal husbandry, credit for buying goats/chickens, developing vegetable gardens, setting up tea shops, bee keeping, sewing/tailoring, credit to buy sewing machines, etc. With respect to trafficking, the underlying assumption is that improved economic opportunities in the rural areas will prevent women and girls from needing to migrate and from being trafficked in the process. This assumption makes intuitive sense. As a strategy that aims to improve rural livelihoods, however, it can perhaps more accurately be described as a migration or community development strategy, in the sense that it aims to address a general need to migrate due to poverty. Its effects on trafficking are only indirect or incidental (though these strategies are usually combined with awareness raising activities). To date, the income generation strategies of the NGOs reviewed did not appear to have been thoroughly evaluated and it is not clear to what extent they do actually succeed in improving rural livelihoods and whether any improvements made are sufficient to offset the need to migrate due to poverty. The extent and accuracy with which activities are targeted at the most needy or 'at risk' (and the way in which this might be defined) is again not clear.

Appendix 2 provides a summary and analysis of the rural trafficking prevention programs that were studied for this report.

\subsection{Urban- and Workplace- Based Programs}

Rural prevention programs can address only the first step in a trafficking process (the initial movement of a person). They are unable to address any subsequent movement or workplacebased exploitation. Anecdotal evidence cited by the NGOs appears to indicate that trafficking from urban work sites is increasing (ABC Nepal 1998). There is a need for a greater focus on the cities. Only one NGO interviewed for this report works directly on trafficking prevention in urban areas or in urban workplaces. One NGO planned to do so.

The main targets of the existing intervention are the carpet factories in Kathmandu. The main activities are: (i) awareness raising and advice giving, and (ii) referring women and girls in trouble (subject to domestic violence, workplace harassment, severe debt and marital/boyfriend problems) to other organizations.

This intervention is run by an NGO that was established by survivors of trafficking. These victims returned to Kathmandu and formed an NGO-supported group to work collectively on trafficking issues. At the time of the research, they had been working for only one year (for more details see Section 7). In this time, they had implemented an awareness-raising program in some carpet factories but their program had lost its momentum at the time of this report. Their experience is instructive for future work. The original idea had been to run awareness raising programs in factories and to form groups of workers who could support each other and who could also act as peer educators. Thirteen women were actually trained as peer educators but at the time of this study only four were still working. There was a high 
turnover of workers, which led to the breakup of groups. The NGO did not appear to have fully developed a strategy for long-term support and motivation of the peer educators, and there were problems with some who felt they should be paid. The NGO found that carpet workers generally dislike their work and are always looking out for other opportunities. There were reports of sexual harassment and exploitation at the factory. Women reported that they rarely received their salaries on time and that the largest part of their salaries went to their families. The NGO did not actively discourage women from moving on but tried to inform them of the dangers of trafficking. Those with particular needs were referred to other organizations (e.g., those dealing with domestic violence). This NGO is also planning to do awareness raising work with young girls living with their families in migrant colonies around Kathmandu.

Another NGO is planning to start work in carpet factories and hopes to eventually open a shelter for women in need, and start working with domestic servants.

The experience cited above shows that trafficking prevention in a workplace context is difficult. It illustrates how, as with rural prevention, advice giving alone is most likely not enough and that activities must provide or, as above, be linked to other services so that support systems exist for women/girls who are in difficulty. Establishing a community base or initiating a collective empowerment process among a mobile, heterogeneous and relatively powerless population represents a particular challenge.

Future work in this area might benefit from reviewing lessons learned and methods adopted in other fields. For example, there is a wealth of experience in the HIV field on working with marginalized and mobile populations. These have included strategies such as collective organization, peer education, or setting up drop-in centers where a range of communitydefined services are available (UNAIDS 1999; Evans 1999). Likewise, child-rights and child-labor organizations and trade unions have a great deal of experience working with employers and organizing and providing services for workers (Baker 2000b; Sattaur 1993; Acharya 1998).

Very little is known about the situation of female/child migrants and trafficking in other urban areas of Nepal (or in India) and in other economic sectors. Hence, more research is needed on the situation of female migrant workers in different settings and for different intervention approaches to be developed and piloted accordingly.

A table in Appendix 3 provides a summary and analysis of urban trafficking prevention work.

\section{$\underline{\text { 6.6 Border-Based Prevention Programs }}$}

One of the ten organizations reviewed for this report is conducting trafficking prevention work at three (out of twenty-six) Indo-Nepal border-crossing points. The main aim is to intercept women/girls who are being trafficked.

The NGO works in collaboration with the police, employs trafficking survivors, and posts them at the border to observe daily crossings and to intercept women and girls in suspicious circumstances. Such women and girls are then taken to the police for questioning and if doubt about their situation remains, they are placed in a transit home until a guardian can be 
contacted or, if they do not wish to return home, they are referred to a Kathmandu home run by the NGO for trafficked and other needy women.

Border surveillance is primarily an immigration (but also an anti-trafficking) strategy used all over the world but usually in situations where specific documentation is required for entry into another country. Those lacking the requisite documentation (or who are found to have forged documentation) are identified as illegal immigrants (or as trafficked persons) and various legal processes are set in motion to assess their situation. However, in the case of India and Nepal where no formal documentation is required, border regulation and the identification of trafficked persons is greatly complicated.

The present strategy of informal regulation at selected points by this NGO raises a number of questions. First is the issue of how to accurately distinguish those who are being trafficked from those who are legally migrating or who are simply crossing the border for recreational purposes. At the present time, trafficking is determined from conflicting or hesitant answers being given by the 'suspects' (adult women as well as minors) to the NGO workers and police. For example, if a group of three girls are crossing together and they all give conflicting accounts of what they are doing, then they may be detained on suspicion of trafficking. This is a common sense strategy, but it has never been systematically evaluated to assess its accuracy. While recognizing a well-intentioned desire to protect women's rights, the present ad hoc system could possibly limit a person's freedom or right to mobility. This is particularly the case with respect to adult women. NGO workers who were interviewed for this report noted that women are sometimes "very angry" and ask, "Why have we been stopped?" Some women in the transit homes need to be "convinced" that they were about to be trafficked. Sometimes, admitted an NGO worker, "we have to be harsh with them to make them understand." These comments raise further questions about the nature of care and counseling provided to detainees at the transit homes. Past experience has shown that a welfare approach where an NGO assumes it knows what is best and strongly promotes what it believes is the 'correct' lifestyle for a young woman/girl, is often ineffective and meets with resistance from target populations (Walkowitz 1980; Brandt 1988).

Another question concerns the nature of home assessment and subsequent follow-up of women or girls who are returned to their homes or guardians. This issue will be discussed in greater depth in Section 7 on care and support. However, there does not presently appear to be any kind systematic assessment or follow-up program for the detainees. Hence, the NGO may inadvertently be returning a woman/girl to a difficult home situation and there is nothing to suggest that the same woman/girl may not re-migrate (or be re-trafficked). The effectiveness of the intervention in terms of preventing trafficking cannot, therefore, be assumed without further research. Figures for the numbers of women/girls intercepted, allowed to cross the border, returned home, or sent on to the Kathmandu home were unavailable. Such figures would be extremely helpful for assessing this border prevention strategy. Likewise, more qualitative documentation of different cases would also help to shed light on some of the questions raised above.

At this stage, and based on the limited available evidence, it is difficult to assess the appropriateness and effectiveness of border-based prevention. More research and evaluation of the existing approach is required. In terms of coverage, it is worth noting that only 11 percent of border crossing points are currently covered by this NGO. The majority of border crossing areas, therefore, remain unmonitored. It seems likely that traffickers (especially 
those who operate as part of organized criminal syndicates) would quickly shift their operations to these areas. ${ }^{3}$

A summary and analysis of border-based trafficking prevention is given in Appendix 4.

\section{$\underline{6.7 \text { Monitoring and Evaluation }}$}

Overall, current trafficking prevention work lacks systematic monitoring, documentation, and evaluation. To learn more about the relative efficacy or impact of different approaches, it is imperative that monitoring and evaluation be an integral part of any future project.

Some existing monitoring/evaluation strategies are described below:

1. Monitoring the number of incidents of social mobilization around trafficking (e.g., number of rallies by women's groups, monitoring how many times women's groups discuss trafficking)

2. Monitoring the number of (suspected) trafficked girls intercepted through community surveillance strategies

3. Monitoring the number of women/girls leaving or staying in the village

4. Monitoring numbers of participants in prevention activities (e.g., number of people attending a seminar, number of girls in prevention camps)

5. Monitoring number of IEC materials produced and distributed

6. Monitoring the number of women/girls intercepted at the border

Several of these strategies $(2,3$, and 6$)$ fail to distinguish between trafficking and migration outcomes, since they cannot distinguish between those who were trafficked and those who legitimately migrated. More information is needed on the processes of both trafficking and migration in order to develop indicators that can distinguish between the two. For example, an intervention that emphasizes safe migration could measure changes in processes of migration rather than the number of women migrating.

Several of the strategies focus on process monitoring rather than on program impact. For example, in awareness raising work simply monitoring the number of activities undertaken (e.g., number of street dramas, number of rallies) and the number of people reached gives no indication of the effectiveness of the chosen approach, especially since it is well known that information alone rarely leads to social action. Although monitoring the number of social mobilization activities around trafficking may measure a change in community perceptions and concern about trafficking, it does not assess the impact on trafficking per se.

Development and measurement of impact indicators for trafficking prevention programs are difficult. Some NGOs pointed out that trafficking prevention could only take place within the context of overall community, economic and social development, especially in rural communities. This is a long-term process in which trafficking-specific indicators or outputs may be difficult to identify. They suggested that the current practice of donor agencies that

\footnotetext{
${ }^{3}$ For example, a recent report in the 'Kathmandu Post' about 21 girls rescued from Indian brothels noted that they had apparently been trafficked across the border along the "desolate routes of Birtamod, Dhangadi and Sunauli." None of these places are covered by the present border interception strategy (Oct. 25, 2000 p. 2).
} 
earmark funding for specific 'anti-trafficking' interventions in fact might encourage a shortterm, top-down and piece-meal intervention approach:

"Donor agencies are a big constraint. They most favor welfare approaches because you get a clear output - like a workshop - in a short time. However, real change takes time. They only want quick results but require continuous paperwork - as if we are the clerks and they are doing all the work"

Experience from other fields indicates that donor-driven priorities and short project periods can act as constraints to long-term empowerment processes (Evans 1999).

Organizations need technical support to develop appropriate impact and process indicators and to carry out baseline and follow-up evaluations. As a first step, however, research is required to determine how effectiveness or impact should be measured.

\section{$\underline{6.8 \text { Conclusions }}$}

A great deal of trafficking prevention work is currently being undertaken in Nepal. The present study found that there is still a need for conceptual clarity to be developed on trafficking among some of the NGOs and also, by implication, among the donors who fund them. Interventions that conflate trafficking with sex work and migration and that take a welfare approach may inadvertently compromise women's rights and may not address the reality of their lives (in particular, the need to migrate due to poverty or to escape intolerable home situations). In addition, they may also inadvertently fuel the social stigma against sex workers and those living with HIV, and may make reintegration of returned women more difficult than it already is.

Current interventions place little emphasis on safe migration. In this respect, organizations currently restrict themselves to warning women about the dangers of trafficking or giving limited advice on how to protect themselves (e.g., "note the address of the workplace"). This advice alone is unlikely to prevent trafficking. Interventions should consider developing other mechanisms to protect women who want/need to migrate. These could include, for example, setting up employment agencies, fostering links with urban NGOs who can be referred to in time of difficulty, formulating workplace programs or setting up drop-in centers where a range of advice could be available. These programs need to be based both in rural areas (where most organizations are currently active), but also in city workplaces since these appear increasingly to be used as trafficking transit points.

The complete lack of meaningful impact assessment makes it impossible to assess the effectiveness of current interventions. There is an urgent need for organizations to develop appropriate monitoring and evaluation mechanisms. However, based on the current assessment, interventions that are community-based or workplace-based and that aim to build capacities and set up support systems appear to hold greater promise for action and sustainability than one-time sensitization programs.

\section{Care and Support of Trafficked Women/Girls}

In 1996, 124 Nepali sex workers were rescued from Indian brothels and returned to Nepal. They were assisted by seven NGOs, some of which still continue working with women in difficult circumstances. Unfortunately, apart from a booklet detailing very brief life histories 
of twelve of the original trafficked girls (ABC Nepal 1998), the accumulated experience of these NGOs on reintegration has not been documented or analyzed. In particular, no comprehensive documentation is available on: (1) the factors that contributed to the girls being trafficked, 2) the process of the trafficking itself, and (3) what exactly has happened to them since. Each individual NGO has kept some records of the girls in their care - some more extensive than others - but these have not been collated to help build a more comprehensive picture either of trafficking in Nepal generally, or, more specifically, of the issues for reintegration.

Another wide gap in current knowledge concerns what happens in the long term to the majority of Nepali sex workers and trafficked women who are not picked up by the authorities. It is unclear how often women return to their communities (or not) and what kind of livelihood strategies they subsequently employ (there or elsewhere). There is some anecdotal evidence to suggest that in certain communities where sex work is a common practice, women can return relatively easily. They may set up small businesses (such as tea stalls) and may also marry (Bhatt 1996). Other anecdotal evidence suggests that, after getting used to city life, or due to social problems and stigma at home, women do not like to return to their communities. Rather, they may settle in urban areas. Here again they may set up small businesses or, if they are a sex worker, they may stay in the sex trade directly or indirectly as a madam or a broker (Frederick and Kelly 2000). Further research is required to develop a better understanding of women's current coping and livelihood strategies, and this knowledge could be used to help develop more appropriate and effective reintegration strategies.

\section{$\underline{7.1 \text { General Description of Current Care and Support Programs for Trafficked Girls }}$}

PROGRAM SITE: Most interventions are based in Kathmandu. One organization has a branch in Mumbai for rescuing sex workers.

ACTIVITY: Two organizations actively aim to identify and rescue trafficked women/girls. These and the others also work on assisting trafficking survivors through placement in residential homes. Here they are given counseling, training, or non-formal education. Attempts are made to reunite girls with their families through family counseling or community advocacy. Some return home and receive financial support to start a new life. Others do not or cannot return home and often remain in residential care. Two organizations try to arrange marriages or to provide non-traditional employment skills. One has motivated a group of trafficking survivors to form their own NGO. Some girls are HIV positive. Some of these have been encouraged to return home, others are placed in a separate AIDS hospice. All are given help with medical treatment.

FOCUS: Five NGOs interviewed are working in the area of care and support. One organization works on trafficking as a stand-alone issue, exclusively in rehabilitation. Others have a range of program foci (e.g., child rights, women's empowerment, HIV) but include care and support as part of their programs.

TARGET GROUP: The NGOs work with trafficking survivors, their families and communities and health workers. 
APPROACH: Some NGOs adopt a welfare approach in which girls and families are given prescriptive advice about future options and in which a return to the status quo appears to be advocated. Others aim to empower trafficking survivors and engage in a dialogue with women/girls about their futures.

Figure 4: General Description of Programs of Care and Support for Trafficked Women/Girls

\begin{tabular}{|c|c|}
\hline Program Site & $\begin{array}{ll}\text { - } & \text { Kathmandu } \\
\text { - } & \text { Mumbai, India }\end{array}$ \\
\hline Activity & $\begin{array}{l}\text { - Care and support of girls who return home } \\
\text { (including non-formal education, individual } \\
\text { counseling, skills training, family } \\
\text { assessment, family counseling, community } \\
\text { advocacy, giving seed money) } \\
\text { - Care and support for girls who do not/cannot } \\
\text { return home (usually residential care) } \\
\text { - Care and support of HIV positive girls } \\
\text { (community/family advocacy, provision of } \\
\text { medical treatment, placement in an AIDS- } \\
\text { hospice) } \\
\text { - Rescue of trafficked women/girls } \\
\text { - Legal assistance }\end{array}$ \\
\hline Primary Organizational Focus & $\begin{array}{l}\text { - Trafficking as a stand-alone issue } \\
\text { - Integrated with other program foci }\end{array}$ \\
\hline Target Group & $\begin{array}{ll}\text { - } & \text { Trafficked women/girls } \\
\text { - } & \text { Families } \\
\text { - } & \text { Communities } \\
\text { - } & \text { Health workers } \\
\end{array}$ \\
\hline Approach & $\begin{array}{l}\text { - Welfare } \\
\text { - } \quad \text { Empowerment }\end{array}$ \\
\hline
\end{tabular}

\subsection{The Aim of Care and Support: Conceptual Clarity}

All NGOs agreed that a primary aim of care and support should be to reunite girls with their families and communities. All acknowledged, however, that this was difficult and that in certain circumstances it was neither possible nor desirable. NGOs noted that, given the stigma associated with sex work and with HIV in Nepal and the increasing publicity (often by the NGOs themselves) of the link between working in India and having HIV, where a girl's history was publicly known, communities may refuse to accept her back. Families themselves may also be reluctant to take girls back, fearing social censure or ostracism from the wider community. In addition, families may (with some justification) worry that any loss 
of prestige would affect the marriage chances of other children. They may also fear retribution from the broker from whom they may have received money. The girls themselves may worry about the extra burden they will place upon their parents, especially if they are HIV positive or if they are unlikely to marry subsequently. Therefore, they may themselves be reluctant to return home. The case studies of 12 trafficked girls (ABC Nepal 1998) clearly illustrate that they came from difficult or dysfunctional family environments. In these situations, the family may not be interested in taking the girl back, she herself may not want to go back, or the authorities concerned may have to assess whether it would be in a girl's best interests to return her home or not. Clearly, girls should not be returned to an abusive or otherwise intolerable situation (one NGO cited a case of a sixteen-year-old girl who was being sexually abused by her father at home).

The experience of NGOs shows that care and support cannot automatically be equated with return to the family or community. This raises the questions of, where appropriate, how a return to the community can best be facilitated and, if inappropriate, what to do for girls who are unable or unwilling to return.

\subsection{Returning Girls to their Families: Current Practices}

Once a girl has been delivered into their care, most NGOs undertake a process of initial medical checks and counseling. Some enroll girls into vocational training programs with the aim of providing her with skills that she can use in her village. At some point in this process, attempts are made to contact families. Depending upon available resources, some NGOs visit the family and community (sometimes repeatedly), others just write to them and invite them to come to Kathmandu. If families come to the shelter and if both parties are ready and willing, the girl may be sent home with them. Most NGOs provide her with some seed money with which she can undertake animal husbandry activities or, for example, buy a sewing machine and set up a small tailoring business.

The NGOs noted that it is common for girls to initially be extremely depressed and to display disruptive or inappropriate behavior. Counseling is seen as essential. Some NGOs noted that counseling is difficult and is required on a long-term basis. Only some NGOs have trained counselors available however. Others do their best, but, as noted above, some organizations appear to be rather directive and forceful in their approach in terms of suggesting to women/girls what is good for them as opposed to enabling them to work through their experiences and reach a decision about their future.

Most NGOs have not worked out a systematic process for assessing family circumstances. This is in part due to a lack of resources and workers as girls came from different regions across the country.

Likewise, when families came to Kathmandu, some NGOs described how they carried out intensive 'family counseling.' In most cases this seemed to be focused on encouraging a family to take back their daughter, fostering acceptance of her, ensuring that they did not blame her and encouraging them to be "bold" in the face of community censure. There is little apparent emphasis on working with families to discuss why a girl may have run away or migrated in the first place, what the problem might be, and how one could possibly resolve this. Hence, in spite of theoretically recognizing the problems that some girls had at home, some NGOs appear ambivalent about the extent to which they accept in practice that families could be unsafe and unhappy places for the girls in their care. For example, the 
same NGO that published the twelve case studies of trafficked girls (in which some very unhappy circumstances were detailed), nevertheless maintained that family reunions invariably represented a 'happy ending' for the girls:

"They had every right to return to their home... it was the duty of everyone to welcome them and give them sympathy and love... The response of the parents and family members to the girls was very positive. . The majority of the parents wanted to take their daughters home as soon as possible. . The parents were so glad" (ABC Nepal 1998:4).

For girls who had returned home, it was unclear what kind of follow-up the girls and their families were given. Again, most NGOs do not appear to have worked out any kind of systematic follow-up strategy, and this is related to lack of resources. Where community censure was great, some NGOs did conduct community visits to encourage tolerance and acceptance on an ad hoc basis (Bhatt 1996).

The vocational training provided in most of the Kathmandu shelters is mainly limited to traditional sewing and knitting skills. It is not clear whether girls are able to put these to use in a profitable way in the village. Likewise, no data are available on the ways in which seed money has been used and the extent to which it can help a girl's economic situation or prevent the need to migrate again in the long term.

Two NGOs are making concerted efforts to expand the range of training provided but note that finding good jobs in non-traditional sectors is very difficult for women. One NGO had trained girls as village health workers and had even provided computer training. Another NGO noted that a prime need of trafficked girls is to rebuild their self-confidence and selfesteem. They felt that skills training could be an important way of doing this and suggested that girls who could return home with useful or prestigious skills (e.g., as health workers), would be more able to hold their head up high and find a sense of self-worth. However, no systematic evaluation of the effectiveness of training in non-traditional sectors has been carried out to date.

This NGO also pointed out that useful skills training combined with effective counseling is $a$ long-term undertaking. Some girls had spent two years in their care before returning home. Even then, out of 14 trafficked girls (whom they had given places to in 1996), three married, three died, two are in the village and the remaining six ultimately returned to Kathmandu. The NGO encouraged these girls to set up their own group, and, as described in Section 6, they have now been registered as an NGO working on trafficking and women's rights.

\subsection{Girls Who Do Not/Cannot Go Home: Current Practices}

Women/girls who cannot or do not want to return home have very few options. The only option at present seems to be living long term in a residential home. Some of the girls who were returned in 1996 are, five years later, still in homes in Kathmandu and elsewhere. Here they contribute to their upkeep through undertaking traditional handicrafts or farming. Some have been employed by the NGOs as wardens in the homes and some are employed at the borders to help intercept trafficked girls. However, there does not appear to be any long-term strategy worked out for their futures. This again, is related to a lack of capacity and resources among the NGOs who are caring for them. Some girls were only teenagers when they returned to Nepal. The present situation in which these girls must face a lifetime in 
residential care is clearly unacceptable, though the NGOs are doing their best. Undeniably, it is extremely difficult for a young, poor, single woman to forge an independent life for herself in the South Asian context. However, NGOs in other countries have considerable experience of supporting women and children in such situations and may have important lessons to share. For example, these include providing useful (non-traditional) training, assisting with job hunting, supporting more independent living (in a hostel or group accommodation), and helping with arranging marriages (Sangroula 2000).

There is clearly a need to support NGOs in their work in this area and to formulate a strategy of long-term support for girls who do not return home.

In sum, it is clear that family reintegration is difficult. More research and resources are required to determine the situation of returned girls and to determine the most effective strategies. This includes assessing the nature of support that NGOs or other agencies require to most effectively help women and girls in need. Current strategies are developed from a welfare orientation in which girls are given traditional skills, told what to do, and the only option presented to them is to return home or remain in residential care. Two organizations have begun to develop alternative ways of supporting trafficking survivors that emphasizes building self-esteem and fostering independent living, but no impact evaluation has yet been carried out.

\subsection{Rescue and Interception Strategies}

As noted in Section 6, one NGO actively attempts to intercept women and girls who are potentially being trafficked at the borders. The same NGO has opened a branch in Mumbai and is actively developing a strategy of raids and rescues in the city's brothels.

One NGO is conducting another type of rescue program that works primarily on child rights and child labor issues in Kathmandu, but the NGO has also been involved in supporting trafficking survivors in 1996. As part of their child-focused work, they have arranged with other NGOs that any incidents of child abuse (which may or may not include trafficking) could be reported to them and they would take action. They also run a shelter for children who need to be removed from difficult situations. With such a strategy, coverage and detection of abuse may not necessarily be systematic but the organization's links and good relationships with other NGOs ensure a greater potential for coverage than could be achieved by working alone. The NGO also operates a telephone hotline.

\section{$\underline{\text { 7.6 Care and Support of Girls who are HIV positive: Current Strategies }}$}

A sizable percentage of the girls who were returned from Mumbai were found to be HIV positive (exact figures are not available). Some required medical treatment for HIV-related and other illnesses. NGOs report that a great deal of advocacy work was required with health services to obtain this treatment. Stigmatization and reluctance to take on HIV positive patients are reportedly still problems.

Some HIV positive girls were helped to return home (as described above). There is no comprehensive follow-up information on the condition of these girls. However, NGOs report that considerable effort was required to convince families and communities to accept them back (Bhatt 1996). Those girls who could not return home remained with the NGOs. 
One NGO has dealt with the issue by opening a separate "AIDS Hospice" in a remote district far from Kathmandu. Approximately $30 \mathrm{HIV}$ positive girls have been sent to live there under the care of a staff nurse. Here the girls participate in agriculture, animal husbandry, and kitchen gardens. There appears to be no long-term program worked out for them.

The rationale given for the special home was that the girls could receive better care there than in Kathmandu. However, for girls who become acutely sick with HIV-related illnesses, Kathmandu offers far better medical treatment options than a remote district and also has a greater number of NGOs offering HIV related services.

\subsection{Legal Assistance}

Two NGOs are currently working to prosecute traffickers and assist trafficking victims present their cases in court.

One of the NGOs focuses on trafficking and started its legal aid section in 1997. Due to resource constraints, they have only one full-time advocate. This organization has registered and followed up almost 100 cases all over the country. They are currently monitoring cases of girls rescued in the course of their other trafficking interventions.

The second NGO is a legal organization with more lawyers. They have about 25 cases in Kathmandu and approximately 200 cases that their branch organizations (with trained lawyers) in the districts are representing. They assist women who are referred from other organizations, women involved in cases in the districts in which they are working, and those cases that advance to the Supreme Court in Kathmandu. Assistance currently focuses on victim support (financial and moral through presence at the hearings) and helping the government attorney in arguing the case and providing guidance in the investigation. Currently, their major emphasis is on surveillance of suspicious movement in their project area through the paralegal committee. They plan to open a separate section with a violence and trafficking hotline that will offer counseling and advice on court representation.

Constraints: According to the sources interviewed, lack of workers and basic infrastructure are major constraints to proper monitoring and following up cases. Often victims are much more comfortable receiving support from a female rather than a male lawyer and more female support staff are needed to escort victims to the court hearings in different parts of the country. A lack of photocopies, audiotapes, and basic equipment to record statements and court rulings make it difficult to adequately prosecute cases to the end. Other constraints include corruption and complicity of judges, lawyers and other court employees and a generally hostile environment that is quite intimidating for young victims. The judges and even the government advocates often seem unsympathetic toward the victims, as indicated by these court interactions:

"You are a bad charactered girl. Why did you go to Bombay without seeking your parents permission?" (Judge)

"A girl who ate only millet rice, was brought to Kathmandu, was given good meat to eat, kept in a lodge for a few days and given a good chance to enjoy life, but look she has filed a case against the poor man now." (Supreme Court government advocate fighting a victim's case) 
"Did you go by your own will/willingly? If so you are not trafficked!" said a judge. Lawyers objected on the grounds that the girl was misled about the ultimate destination.

An average case stretches from two to five years, and the NGO needs to remain in contact with the victim throughout this period. An average case costs 20-25,000 Nepalese rupees (approximately US\$ 300). The victim must be present for the "First Information Report (FIR)" and the initial hearing in the court. The gap between the two events can range from one to three years.

Both NGOs cited the need for improved police investigative techniques and the need for constant support and guidance to girls to prosecute traffickers. Most cases receiving NGO assistance are prosecuted and sentenced. The problem is mainly with the cases that are not monitored by the NGOs. If the trafficked girl can corroborate her FIR statement in the first court hearing, and the culprit is caught, they are usually sentenced. The problem lies with the slow court process. The gap between filing the FIR and the first hearing can stretch up to a maximum of two years. A large number of cases are either dismissed or settled out of court by the traffickers and the girl's family. To convict trafficking criminals, one NGO recommended the victims should be kept in safe shelter homes for the period of the court case. This sheltering alleviates pressure on the girls in their own community and family ("They need to be away from their parents."), and ensures regular follow-up.

The other organization reported that keeping these girls in a shelter for the entire court hearing was not feasible. Therefore, they limit their assistance to monitoring cases in the initial critical phase for girls who seek assistance at the central or state level. Though they help in monitoring the proceeding, the responsibility to keep in contact rests with the girls and not the NGO. The NGO representative reported that the only major problem in prosecution is the non-cooperation and insensitivity of the police and legal officials. "If this aspect is corrected almost 90 percent of cases will be successfully prosecuted since the laws are favorable to the trafficked."

In a small percentage of cases, the NGOs have been accused of making false charges and stopping the wrong person at the borders or in transit or source areas. These persons have accused the NGOs and police of harassment and asking offensive questions. The NGOs claim that the majority of those caught are criminals and traffickers, and it is only due to lack of evidence that a few are freed.

\section{$\underline{7.8}$ Monitoring and Evaluation}

As noted above, there is a lack of monitoring or evaluation in current care and support programs. In particular, there is a need for:

1. Documentation, analysis and assessment of lessons learned from existing work with trafficking survivors

2. Evaluation of current individual and family counseling programs

3. Evaluation of current family assessment strategies

4. Impact evaluation of current skill training/income generation activities

5. Evaluation of current follow-up strategies for girls who have returned home (to potentially difficult circumstances) 
6. Evaluation of the appropriateness of current care and support for HIV positive girls, especially those in the AIDS hospice

7. Monitoring of numbers of girls who are 'rescued,' number of these who do or do not return home and long-term follow-up of their subsequent lives as part of an overall evaluation to assess the appropriateness of current strategies and to develop better ones

\section{$\underline{7.9 \text { Conclusions }}$}

This section has examined the complexity and difficulty of care and support for trafficked women/girls. The best future strategy for a trafficked girl may or may not involve reintegration into families/communities. Welfare-oriented organizations appear to prescriptively suggest only limited options, whereas empowerment-oriented NGOs have made some progress in formulating ways in which women/girls can be helped to make their own decisions and gain the confidence to act upon them.

In the case of reintegration, a particular challenge lies in developing profitable rural livelihood strategies for a girl and in following up her progress. Perhaps a more formidable challenge is in developing appropriate support strategies for those who do not return home. Present options are limited, but again, some NGOs are beginning to develop strategies to support empowered and independent living. These warrant further support.

Care and support of HIV positive girls is another area of concern. Community-based care is difficult but NGOs have shown it to be possible. The present strategy of segregation of HIV positive returnees needs further investigation.

Rescue and interception strategies are necessary, but the report findings (in this section and in Section 6) suggest that they must be predicated upon a clear understanding of 'trafficking' (as opposed to voluntary sex work or migration) and must have well thought out and well resourced facilities to provide subsequent care and support. These are currently lacking.

Monitoring and evaluation of current programs are lacking. A detailed and thorough documentation of existing experiences/knowledge and a follow-up research program of girls who have returned would go a long way towards filling gaps in present understanding and in identifying specific needs for future action and capacity building.

Appendix 5 presents a summary table and analysis of care and support of trafficked women/girls.

\section{Advocacy and Networking}

Advocacy and networking-related activities were not studied in great depth for this report, and only a few points in this regard will be made. There are presently three networks in Nepal, which potentially concern themselves with trafficking. Two networks (AATWIN and NNAGT) are focused only upon trafficking, whereas a third, Children at Risk (CAR), is focused on 'children at risk' but includes trafficking in its activities. At the time of the research, one NGO was planning to align itself primarily to another regional network, Alliance Against Trafficking and Sexual Exploitation of Children (ATSEC). In the presence of so many networks, there is clearly some potential for overlap and duplication of activities. This has implications both in terms of efficient use of resources and in terms of the 
effectiveness of the activities. The networks, NNAGT, AATWIN, and ATSEC, appear to be split by ideological and political differences, reflecting the differences between the two global anti-trafficking alliances, CATW and GAATW (see Section 3.2). NNAGT and ATSEC equate trafficking with sex work and migration and take a welfare approach, including, advocating tighter restrictions on women's travel resulting in the 1999 Foreign Employment Act requiring women under 35 to have permission of a guardian to travel. AATWIN by contrast de-linked trafficking from sex work, migration and HIV and was beginning to develop a safe migration emphasis. However, both networks appear to be engaged in awareness and advocacy activities with the same target groups (e.g., parliamentarians or the police). Hence, conflicting messages and inconsistent advice are being given out.

Efforts should be made to help the various networks come closer together and to develop a more common platform. An emphasis on the generic protection of human rights (as opposed to discussing the moral rights and wrongs of sex work or migration) may assist in bridging current ideological gaps. Likewise, networking and advocacy activities should be coordinated to avoid unnecessary duplication or confusion.

\section{Key Findings, Gaps and Recommendations}

\section{CONCEPTUAL CLARITY}

- There is a need for NGOs and donor agencies to develop conceptual clarity on trafficking - in particular, on its relation to migration and sex work. Some interventions currently conflate these concepts leading to strategies that may (explicitly or implicitly) restrict women's freedom and right to mobility. This is particularly true in welfare-oriented interventions in which NGOs claim to know what is best for women/girls (including whether or not they should be allowed to migrate). Lack of conceptual clarity affects all phases of a project, including monitoring and evaluation. For example, some organizations equate keeping women in the village with success preventing trafficking.

- Conceptual clarity is also important in terms of understanding how 'vulnerability' to trafficking is conceived and, consequently it has implications for the way in which some programs target 'at risk' groups.

- Adopting a human rights framework and basing interventions on sound research (see below) may help to clarify current trafficking discourses.

\section{$\underline{\text { RESEARCH }}$}

- There is a need for more research that informs intervention strategies and their subsequent monitoring and evaluation. Current information is largely anecdotal. Research should include:

- Analysis of the socio-economic context and process of female labor migration in Nepal and its linkages with trafficking. An understanding of this is fundamental to the development of appropriate intervention strategies.

- Documentation of known trafficking cases to develop a clearer picture of current trafficking methods, sites and processes, and also to develop a clearer picture of who is at risk and why and how to define vulnerability. This would assist the appropriate targeting of interventions. 
- Documentation and follow-up of 'rescued' and 'intercepted' trafficked women/girls, including those who do and who do not return home to their families, and those who are HIV positive. Again, this would help develop a better understanding of vulnerability and is important to inform and refine care and support strategies.

- Research on the livelihood and coping strategies of other sex workers and female migrants who return to Nepal. This would help to inform care and support strategies.

- Experience indicates that research specifically on trafficking is best conducted by NGOs that have a strong field presence and that have built up trust in their target communities.

\section{PROGRAM SITE}

- Rural/Urban: Current evidence suggests that trafficking of female and child migrants from urban work sites is common and increasing. However, most prevention work to date focuses upon rural areas. There is a need to broaden the focus of trafficking prevention efforts to include the cities and urban workplaces.

- Border: Current, border-based prevention strategies require further assessment to determine their effectiveness and to ensure that women's right to mobility is not being breached.

\section{PROGRAM CONTENT}

- Prevention: Most preventive interventions focus on: (i) improving women's opportunities in the village, (ii) keeping women in the village, and (iii) giving warnings about the potential dangers of trafficking and migration. These are valid activities but some IEC messages do not appear to be based on an informed understanding of local migration processes or on community needs/priorities. Given the reality that many women DO migrate or are trafficked, and that trafficking may occur in city workplaces as well as directly from rural areas, IEC materials need to be realistic and relevant and should include concrete relevant advice on how to migrate safely. There is also a need to establish support systems to enable safe migration and to help women once they are in the cities.

- Care and Support: Current evidence suggests that care and support of rescued girls is a difficult and long-term process. NGOs engaged in this work require technical and financial support to develop systematic techniques for family assessment, counseling, intervention, and follow-up. Particular help is required to develop appropriate plans for girls who cannot return home and for those who are HIV positive. In particular, one current strategy of segregating HIV positive 'rescued' girls in a home in a remote district requires careful evaluation.

\section{PROGRAM PROCESS}

- Prevention: Evidence from this report and from experience in other fields suggests that interventions that work from the bottom-up, that involve communities, build capacities and that aim to establish systems (e.g., women's groups) for providing support and taking action appear to hold greater promise for action and sustainability than top-down interventions that are characterized by one-time sensitization programs. Likewise, interventions that are empowerment-oriented and that, through a process of dialogue, aim to facilitate informed decision-making (e.g., on whether or not to migrate), are more 
likely to be relevant to community realities and to be accepted by target groups than those that are welfare-oriented and paternalistic in approach (telling people what is best for them).

- Care and Support: Currently most care and support programs are welfare-oriented in which women/girls are provided with limited options, given directive counseling, and given traditional skills training and jobs. However, some programs are empowermentoriented and aim to provide a range of skills and options to enable independent living and to build up self-esteem. The latter appears to be a promising approach but NGOs require assistance to develop these programs further.

\section{ADVOCACY AND NETWORKING}

- There is a need for coordination and consistency in current advocacy work. An emphasis on promoting human rights and promoting safe migration may help to overcome some of the ideological differences (particularly with respect to sex work) that currently divide the field.

- NGOs working to prosecute anti-trafficking cases require more support. The cases they pursue should be documented and used in advocacy work with the judiciary.

\section{MONITORING AND EVALUATION}

- Though a great deal of trafficking-related work is being done, most interventions have not been systematically documented or evaluated and on-going monitoring of programs is absent, ad hoc, or is insufficiently rigorous. Hence, at this stage, it is not possible to make informed judgments of an intervention's relative efficacy or sustainability. There is an urgent need to support NGOs to develop appropriate monitoring and evaluation mechanisms. Some formative research may first be required to develop appropriate process and impact indicators. Thorough documentation and sharing of experiences would greatly help to identify lessons learned and to build up a better understanding of which approaches work/do not work and why. This may be particularly useful for care and support strategies.

\section{POTENTIALLY INNOVATIVE INTERVENTION APPROACHES}

\section{Prevention}

- Community surveillance appears to be a good example of how community involvement combined with outside support may assist communities to establish systems that can take action in the event of suspected trafficking and that can help those in difficulty. However, care must be taken not to equate women leaving the village with trafficking. Similarly, care must be taken not to abuse the system, so that it does not become a mechanism for controlling women/girls.

- Establishing women's groups who can provide support and who can take action in the event of problems is also a promising anti-trafficking strategy. Such groups can be used as a forum for advice giving and for support and shelter to those facing family or financial problems who might otherwise be tempted to run away or leave the village via an unsafe route (e.g., with an unknown broker).

- Working with children/young people through schools, teachers or child clubs appears to be an innovative anti-trafficking strategy. Peer support/influence is harnessed and the 
groups/clubs may act as neutral forums where children who are experiencing family problems can seek help.

- Involving trafficking survivors is another promising strategy. Their involvement may be useful: firstly, in order to make anti-trafficking messages more realistic and relevant to particular target groups. Experience in other fields has shown that people are more likely to identify with peer-led education rather than that given by social workers. Secondly, the example of one NGO that helped trafficking survivors to set up their own organization shows that their involvement can also play an important part in the rebuilding of their own self-esteem and confidence, and may act as an important capacity building opportunity.

- The intervention in Kathmandu (run by the NGO formed by trafficking survivors) is also an innovative approach to preventing trafficking by trying to tackle the problem at a different and increasingly significant stage in the trafficking/migration process.

\section{Care and Support}

- Interventions that aim to empower women/girls who have been trafficked, and that do so through an empathetic and dialogical process of counseling, and that offer a variety of future options (including non-traditional ones) appear to show the way forward for care and support (although implementation is acknowledged to be extremely difficult in the South Asian context). These interventions include supporting and encouraging trafficking survivors to be actively involved in gender rights programs and offering training and career options that raise self-esteem, build confidence and offer opportunities to break away from traditional gender stereotypes to enable a process of independent living. 
Figure Five: Summary of Key Gaps, Findings and Recommendations

\begin{tabular}{|c|c|c|}
\hline ISSUE & KEY GAP/FINDING & RECOMMENDATION \\
\hline Conceptual Clarity & $\begin{array}{l}\text { - Lack of clarity on meaning and } \\
\text { process of trafficking and on } \\
\text { vulnerability to trafficking } \\
\text { - Some organizations wrongly } \\
\text { conflate trafficking with sex work or } \\
\text { migration - leads to intervention } \\
\text { strategies that may (inadvertently) } \\
\text { compromise women's freedom and } \\
\text { right to mobility. } \\
\text { Method of defining 'at risk' groups } \\
\text { for targeted interventions is unclear. }\end{array}$ & $\begin{array}{l}\text { Organizations need to } \\
\text { develop conceptual clarity } \\
\text { on trafficking. } \\
\text { Adopting a human rights } \\
\text { framework may clarify } \\
\text { current points of confusion. } \\
\text { - Further research can help } \\
\text { clarify the nature of } \\
\text { vulnerability to trafficking } \\
\text { and hence indicate the } \\
\text { most appropriate points for } \\
\text { targeting programs. }\end{array}$ \\
\hline Research & $\begin{array}{l}\text { - Lack of research with which to } \\
\text { develop informed intervention } \\
\text { strategies }\end{array}$ & 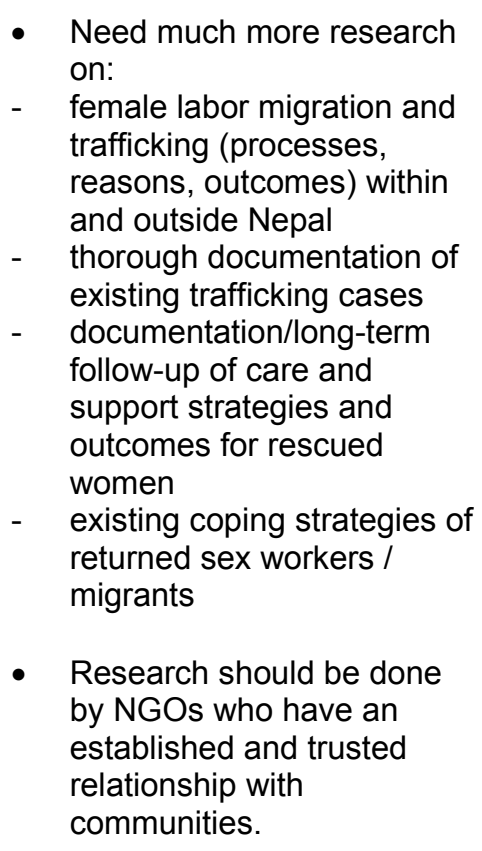 \\
\hline Program Site & $\begin{array}{l}\text { Main focus of interventions is on } \\
\text { rural areas. Evidence indicates that } \\
\text { trafficking is increasingly becoming } \\
\text { an urban phenomenon. } \\
\text { - Effectiveness of border-based } \\
\text { interception strategies is unclear. }\end{array}$ & $\begin{array}{l}\text { - Interventions should } \\
\text { expand to cover city } \\
\text { workplaces and to support } \\
\text { female migrants. } \\
\text { - Needs further investigation }\end{array}$ \\
\hline $\begin{array}{l}\text { Program Content } \\
\text { (a) prevention }\end{array}$ & $\begin{array}{l}\text { - Overall lack of relevant, realistic } \\
\text { IEC messages }\end{array}$ & $\begin{array}{l}\text { IEC should be based on } \\
\text { research on migration, } \\
\text { trafficking, and community } \\
\text { needs. }\end{array}$ \\
\hline
\end{tabular}




\begin{tabular}{|c|c|c|}
\hline ISSUE & KEY GAP/FINDING & RECOMMENDATION \\
\hline $\begin{array}{l}\text { Program Content } \\
\text { (continued) } \\
\text { (a) prevention }\end{array}$ & $\begin{array}{l}\text { - Lack of information and support } \\
\text { systems for safe migration } \\
\text { - } \quad \text { Lack of systematic care and } \\
\text { support strategies, especially in the } \\
\text { areas of counseling, family } \\
\text { assessment, training, follow-up and } \\
\text { care of HIV positive girls } \\
\text { Current situation in which girls who } \\
\text { cannot return home must reside for } \\
\text { years (or indefinitely) in residential } \\
\text { homes is unacceptable. }\end{array}$ & $\begin{array}{l}\text { - Need to give advice on safe } \\
\text { migration and set up } \\
\text { mechanisms to promote } \\
\text { safe migration and protect } \\
\text { women's rights. } \\
\text { - Experiences to date of } \\
\text { NGOs doing care and } \\
\text { support should be } \\
\text { documented and lessons } \\
\text { learned identified. } \\
\text { Current strategies need } \\
\text { further in-depth } \\
\text { investigation to assess their } \\
\text { appropriateness. } \\
\text { NGOs require technical and } \\
\text { financial support to develop } \\
\text { their programs. }\end{array}$ \\
\hline $\begin{array}{l}\text { Program Process } \\
\text { (a) prevention } \\
\text { (b) care and support }\end{array}$ & $\begin{array}{l}\text { Programs that are bottom-up, } \\
\text { based in communities and } \\
\text { empowerment oriented are more } \\
\text { likely to be relevant, to promote } \\
\text { human rights, to build capacities } \\
\text { and to be sustainable. } \\
\text { There is a complete lack of } \\
\text { monitoring, evaluation or } \\
\text { documentation of current programs. } \\
\text { Hence it is difficult to make } \\
\text { informed judgments about the } \\
\text { relative advantages or } \\
\text { disadvantages of different program } \\
\text { processes. }\end{array}$ & $\begin{array}{l}\text { - These kinds of programs } \\
\text { deserve further assessment } \\
\text { and support. } \\
\text { - } \begin{array}{l}\text { Monitoring, evaluation and } \\
\text { documentation should be } \\
\text { an integral part of future } \\
\text { programs. }\end{array}\end{array}$ \\
\hline $\begin{array}{l}\text { Monitoring and } \\
\text { Evaluation }\end{array}$ & - As above & $\begin{array}{l}\text { - As above } \\
\text { The development of } \\
\text { appropriate process and } \\
\text { outcome indicators may } \\
\text { require some initial } \\
\text { formative research. }\end{array}$ \\
\hline $\begin{array}{l}\text { Advocacy and } \\
\text { Networking }\end{array}$ & $\begin{array}{l}\text { - Lack of coordination between } \\
\text { different network activities }\end{array}$ & $\begin{array}{l}\text { Emphasis on human rights } \\
\text { may help to breach present } \\
\text { ideological divide. }\end{array}$ \\
\hline
\end{tabular}




\begin{tabular}{|c|c|c|}
\hline ISSUE & KEY GAP/FINDING & RECOMMENDATION \\
\hline & $\begin{array}{l}\text { Inconsistent messages are being } \\
\text { given to same target groups. } \\
\text { Ideological/political differences are } \\
\text { a barrier to building a common } \\
\text { advocacy platform. }\end{array}$ & \\
\hline $\begin{array}{l}\text { Innovative } \\
\text { Intervention } \\
\text { Approaches } \\
\text { (a) prevention }\end{array}$ & $\begin{array}{ll}- & \text { Promising trafficking prevention } \\
\text { - } & \text { approaches include: } \\
\text { - } & \text { working with women's groups } \\
\text { - } & \text { working with children's groups (e.g., } \\
\text { - } & \text { child clubs/schools) } \\
- & \text { involving trafficking survivors } \\
- & \text { working in urban workplaces } \\
& \text { taking an empowerment-oriented } \\
& \text { approach }\end{array}$ & $\begin{array}{l}\text { - Strategies require technical } \\
\text { support and on-going } \\
\text { evaluation. }\end{array}$ \\
\hline (b) care and support & 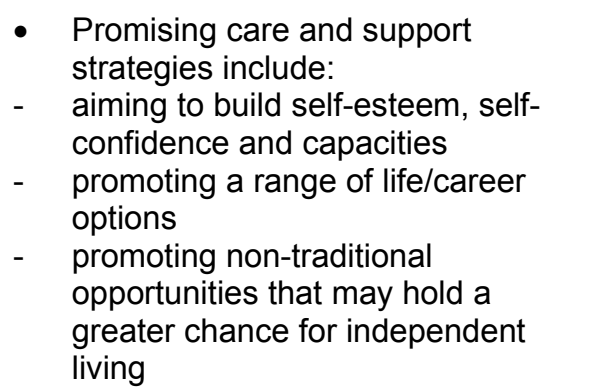 & $\begin{array}{l}\text { Strategies require technical } \\
\text { support and on-going } \\
\text { evaluation. }\end{array}$ \\
\hline
\end{tabular}




\section{References}

ABC Nepal. 1996. Redlight Traffic: The Trade in Nepali Girls. Kathmandu: ABC Nepal.

ABC Nepal. 1998. Life in Hell: The True Stories of Girls Rescued from Indian Brothels. Kathmandu: ABC Nepal.

Acharya, U. 1998. "Trafficking in Children and the Exploitation in Prostitution and Other Intolerable Forms of Child Labor in Nepal: Nepal Country Report," (unpublished), prepared for ILO-IPEC. Kathmandu.

Adhikari, R. 1997. “Nepal's Lost Daughters, India's Soiled Goods: An Analysis of Returned Sex Worker's Situation in Nepal," (unpublished). M.Sc. Thesis, London School of Hygiene and Tropical Medicine.

AIDS Action. 1998. People on the Move, Edition on HIV and Migration, Issue no. 40, JulySeptember.

All India Institute of Hygiene and Public Health (AIIHPH). 1993a. "Assessment of Sex Trade in Calcutta and Howrah," (unpublished). Calcutta, Department of Epidemiology, AIIHPH.

Baker, R. and C. Panter-Brick. 2000. "A Comparative Perspective on Children's 'Careers' and Abandonment in Nepal," in Abandoned Children, Panter-Brick, C. and M. Smith (eds.). U.K.: Cambridge University Press, pp. 161-182.

Bhatt, P. 1996. "Melemchi: A Case Study in Community Mobilisation,” in Redlight Traffic: The Trade in Nepali Girls, ABC Nepal (eds.). Kathmandu: ABC Nepal, pp. 56-64.

Brandt, A. 1988. "AIDS: From Social History to Social Policy," in AIDS: the Burdens of History, Fee, E. and D. Fox (eds.). Berkeley: University of California Press, pp. 147-172.

Center for Women and Development (CFD). 1996. "Survey of Organizations Working on the Issues of Girl Trafficking" (unpublished), report prepared for The Asia Foundation, Kathmandu.

Coalition Against Sexual Exploitation of Women (CATW). 1999. "Declaration of Rights for Women in Conditions of Sex Trafficking and Prostitution," re/productions, no. 2, April.

Coomaraswamy, R. 1997. Report on Trafficking of Women submitted in Accordance with Commission on Human Rights Resolution 1997/44/E/CN.4/2000/68 at the $56^{\text {th }}$ Session of the Commission on Human Rights, January 2000, Geneva.

Doezema, J. 1998. "Forced to Choose: Beyond the Voluntary v. Forced Prostitution Dichotomy," in Global Sex Workers: Rights, Resistance and Redefinition, Kempadoo, K. and J. Doezema (eds.). London: Routledge, pp. 34-51.

Evans, C. 1999. An International Review of the Rationale, Role and Evaluation of Community Development Approaches in Interventions to Reduce HIV Transmission in Sex Work, (unpublished), report prepared for the Horizons Project, Population Council, New Delhi. 
Frederick, J. 1998. “Deconstructing Gita”, Himal, vol. 11, no. 10, pp. 12-23.

Frederick, J. and T. Kelly (eds.). 2000. Fallen Angels: The Sex Workers of South Asia. New Delhi: Lustre Press, Roli Books.

Gordon, P. and C. Sleightholme. 1996. Review of Best Practice for Targeted Interventions, report submitted to ODA (now DFID), New Delhi.

International Labor Organization/International Program on the Elimination of Child Labor (ILO/IPEC). 1998. "Trafficking in Children for Labor Exploitation, including Sexual Exploitation in South Asia: Synthesis Paper, (unpublished), Nepal, South Asian Sub-regional Consultation.

Jenks, C. 1996. Childhood. London: Routledge.

Kempadoo, K. and J. Doezema (eds.). 1998. Global Sex Workers: Rights, Resistance and Redefinition. London: Routledge.

King, R. 1999. "Sexual Behavioural Change for HIV: Where Have Theories Taken Us?" in UNAIDS Best Practice Collection. Geneva: UNAIDS.

Ministry of Women, Children and Social Welfare (MOWCSW), His Majesty's Government of Nepal, 1998. National Plan of Action against Trafficking in Children and Their Commercial Exploitation: An Outcome of a Consultative Workshop. Kathmandu, April 2224.

Montgomery, H. 1998. “Children, Prostitution and Identity: A Case Study from a Tourist Resort in Thailand," in Global Sex Workers: Rights, Resistance and Redefinition, in Kempadoo, K and J. Doezema (eds.). London: Routledge, pp. 139-151.

Montgomery, H. 2000. "Abandonment and Child Prostitution in a Thai Slum Community", in Abandoned Children, Panter-Brick, C. and M. Smith (eds.). U.K.: Cambridge University Press, pp. 182-199.

National Living Standards Survey (NLSS). 1995/6. (reference unobtainable, quoted in Seddon et al. 1999).

National Commission on Population (NCP). 1983. Internal and International Migration in Nepal. Task Force on Migration. Kathmandu: NCP.

National Network Against Girl Trafficking (NNAGT). 1999. Migrant Labor and Trafficking of Women, workshop report. Kathmandu: NNAGT.

O'Dea, P. 1993. Gender Exploitation and Violence: The Market in Women, Girls and Sex in Nepal: An Overview of the Situation and a Review of the Literature. Kathmandu: UNICEF.

Panter-Brick, C. 2000. "Nobody's Children? A Reconsideration of Child Abandonment", in Abandoned Children, Panter-Brick, C. and M. Smith (eds.). U.K.: Cambridge University Press, pp. 1-27. 
Poudel, K. 1999. Migration Pattern of Doti, (unpublished). UNDP/NCASC, Participatory Planning and Management of AIDS Program, District Development Committee, District AIDS Liaison Unit, Doti.

Pradhan, G. 1996. Back Home from the Brothels: A Case Study of the Victims of Commercial Sexual Exploitation and Trafficking Across Nepal-India Border. Kathmandu: Child Workers in Nepal Concerned Centre (CWIN).

Pradhan, G. 1996. "The Road to Bombay: Forgotten Women," in Redlight Traffic: The Trade in Nepali Girls, ABC Nepal (eds.). Kathmandu: ABC Nepal, pp. 33-42.

Rajbhandari, R. 1996. Girl Trafficking: Hidden Grief in the Himalayas, (unpublished). Kathmandu: WOREC.

Sanghera, J. 2000. Trafficking of Women and Children in South Asia: Taking Stock and Moving Ahead, (unpublished), report prepared for UNICEF Regional Office South Asia and Save the Children Alliance South and Central Asia.

Sangroula, Yubaraj. 2000. Untitled draft report prepared for Centre for Legal Research and Resource Development (CeLLRd).

Sattur, O. 1993. "Child Labour in Nepal: A Report by Anti-Slavery International and Child Workers," in Nepal Concerned Centre, no. 13, ASI's Child Labour Series.

Save the Children/UNICEF. 2000. Bringing Up Children in a Changing World: Who's Right? Whose Rights?: Conversations with Families in Nepal. Kathmandu: Save the Children/UNICEF.

Seddon, S., J. Jagganath and G. Gurung. 1999. Foreign Labor Migration and the Remittance Economy of Nepal, (unpublished), report prepared for DFID Nepal Country Office.

UNAIDS. 1999. Booklet of Best Practices, Issue 1. Geneva: UNAIDS.

UNAIDS. 2000. Report on the Global HIV/AIDS Epidemic. Geneva: UNAIDS.

United Nations Development Programme. 2000. Population Mobility in Asia: Implications for HIV/AIDS Action Programs. Thailand: UNDP South-East Asia HIV and Development Project.

USAID. 1999. USAID Strategic Framework for the Asia Regional Anti-Trafficking Initiative, (unpublished). Washington D.C.: USAID.

Walkowitz, J. 1980a. Prostitution and Victorian Society: Women, Class and the State. London: Cambridge University Press.

WOREC/CEDPA. 1999. Advocacy Against Trafficking in Women Training Manual, prepared by WOREC and CEDPA. Kathmandu. 


\section{Appendix One}

\section{List of Informants}

\section{Non-Governmental Organizations}

1. General Welfare Prathisthan (GWP)

2. Maiti Nepal

3. ABC Nepal

4. Women's Rehabilitation Center (WOREC)

5. Centre for Legal Research and Resource Development (CeLLRd)

6. Child Workers in Nepal Concerned Centre (CWIN)

7. Shakti Samuha

8. Peace Rehabilitation Center

\section{$\underline{\text { Networks }}$}

National Network Against Girl Trafficking (NNAGT)

Alliance Against Trafficking in Women and Children in Nepal (AATWIN)

\section{International Non-Governmental Organizations}

Save the Children-US

The Asia Foundation (TAF)

\section{Donor Agencies}

United States Agency for International Development (USAID)

\section{$\underline{\text { Other }}$}

Four Key Informants 
APPENDIX TWO: RURAL-BASED TRAFFICKING PREVENTION PROGRAMS: SUMMARY AND ANALYSIS

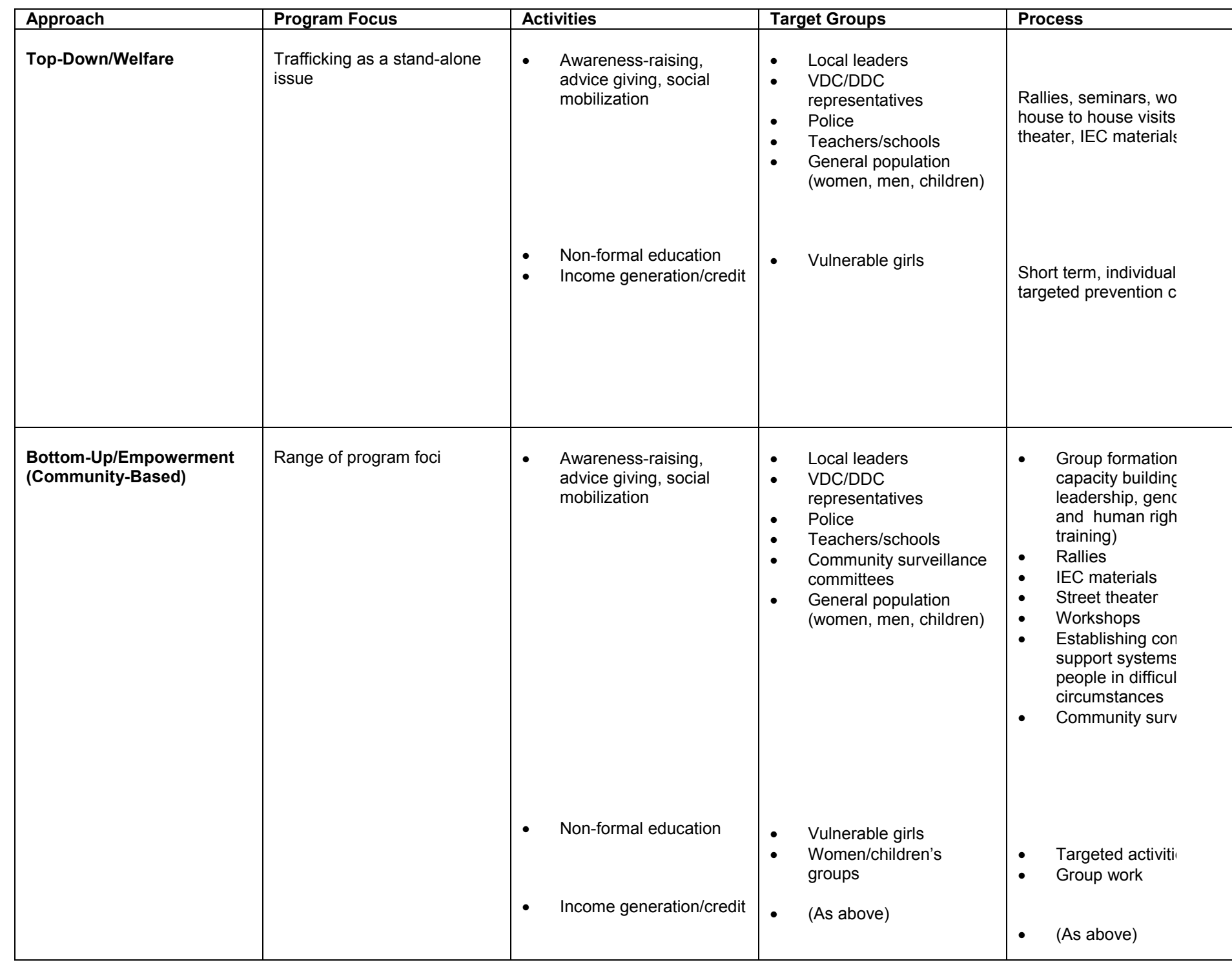


APPENDIX THREE: CITY-BASED TRAFFICKING PREVENTION PROGRAMS: SUMMARY AND ANALYSIS

\begin{tabular}{|c|c|c|c|c|}
\hline Approach & Program Focus & Activities & Target Groups & Process \\
\hline $\begin{array}{l}\text { (Attempted) } \\
\text { Bottom-Up/Empowerment }\end{array}$ & $\begin{array}{l}\text { Trafficking as a stand-alone } \\
\text { issue }\end{array}$ & $\begin{array}{l}\text { Awareness-raising, } \\
\text { advice giving, social } \\
\text { mobilization }\end{array}$ & $\begin{array}{l}\text { Women/girls in } \\
\text { Kathmandu carpet } \\
\text { factories }\end{array}$ & $\begin{array}{ll}\text { - } & \text { Talks/group disc } \\
\text { - } & \text { (Attempted) gro } \\
\text { formation } \\
\text { - } \\
\text { (Attempted) pee } \\
\text { education } \\
\text { - } \\
\text { Referral of wom } \\
\text { in need to other } \\
\text { organizations }\end{array}$ \\
\hline
\end{tabular}


APPENDIX FOUR: BORDER-BASED TRAFFICKING PREVENTION PROGRAMS: SUMMARY AND ANALYSIS

\begin{tabular}{|c|c|c|c|c|}
\hline Approach & Program Focus & Activities & Target Groups & Process \\
\hline Top-Down/Welfare & $\begin{array}{l}\text { Trafficking as a stand-alone } \\
\text { issue }\end{array}$ & $\begin{array}{l}\text { - Interception of } \\
\text { women/girls suspected } \\
\text { of being trafficked } \\
\text { across the Indo-Nepal } \\
\text { border } \\
\text { Detention and } \\
\text { questioning of suspected } \\
\text { trafficking 'victims' at } \\
\text { transit homes } \\
\text { - Counseling } \\
\text { - } \quad \text { Repatriation of } \\
\text { women/girls with families } \\
\text { or referral to other } \\
\text { homes in Kathmandu }\end{array}$ & $\begin{array}{l}\text { - Women/girls suspected } \\
\text { of being trafficked } \\
\text { - } \quad \text { Police }\end{array}$ & $\begin{array}{l}\text { - Use of traffickin؛ } \\
\text { survivors to iden } \\
\text { potentially traffic } \\
\text { women/girls as } 1 \\
\text { cross the border } \\
\text { Collaboration wi } \\
\text { police } \\
\text { Questioning of tI } \\
\text { suspects by NG } \\
\text { police } \\
\text { - Persuade wome } \\
\text { return home }\end{array}$ \\
\hline
\end{tabular}


APPENDIX FIVE: CARE AND SUPPORT OF TRAFFICKED WOMEN/GIRLS: SUMMARY AND ANALYSIS

\begin{tabular}{|c|c|c|c|c|}
\hline Approach & Program Focus & Target Groups & Activities & Process \\
\hline Welfare-Oriented & $\begin{array}{l}\text { - Trafficking as a stand- } \\
\text { alone issue } \\
\text { - } \quad \text { Range of program foci }\end{array}$ & $\begin{array}{ll}\text { - } & \text { Trafficked } \\
\text { - } & \text { Fomen/girls } \\
\text { - } & \text { Comilies } \\
\text { - } & \text { Health workers }\end{array}$ & $\begin{array}{l}\text { - Care and support of } \\
\text { girls who return } \\
\text { home }\end{array}$ & $\begin{array}{ll}\text { - } & \text { Care in residential home } \\
\text { - } & \text { Individual counseling } \\
\text { - } & \text { Family assessment and } \\
\text { - } & \text { Comily counseling } \\
\text { - } & \text { Non-formal education } \\
\text { - } & \text { Traditional skills training } \\
\text { - } & \text { Provision of seed money } \\
\text { - } & \text { return home } \\
\text { - } & \text { Limited follow-up } \\
\text { - } & \text { hong-term stay in residen } \\
\text { - } & \text { Traditional vocational trail } \\
\text { - } \quad \text { Family/community advoci } \\
\text { - } \quad \text { Se encourage acceptance } \\
\quad \text { hospice } \\
\text { - } \quad \text { Rescue from brothels } \\
\text { - } \quad \text { dong-term stay in shelter } \\
\text { during the court process }\end{array}$ \\
\hline Empowerment-Oriented & - $\quad$ Range of program foci & (As above) & $\begin{array}{l}\text { - } \begin{array}{l}\text { Care and support of } \\
\text { girls who return } \\
\text { home }\end{array} \\
\text { - } \quad \begin{array}{l}\text { Care and support of } \\
\text { girls who do not } \\
\text { return home }\end{array} \\
\text { - } \quad \text { Care and support of } \\
\text { - } \quad \text { Rescue positive girls } \\
\text { - Legal assistance }\end{array}$ & $\begin{array}{l}\text { - As above, except skills } \\
\text { training may be non- } \\
\text { traditional (e.g., health } \\
\text { worker) } \\
\text { - } \begin{array}{l}\text { Arrange marriages, non- } \\
\text { traditional skills training a } \\
\text { job placement, self- } \\
\text { organization (registered a } \\
\text { NGO) } \\
\text { - As above except no } \\
\text { segregation } \\
\text { - } \begin{array}{l}\text { Rescue from variety of } \\
\text { abusive situations }\end{array} \\
\text { - Support through court } \\
\text { process without residentic } \\
\text { stay }\end{array}\end{array}$ \\
\hline
\end{tabular}

